Published in final edited form as:

Annu Rev Nutr. 2020 September 23; 40: 273-297. doi:10.1146/annurev-nutr-013120-041149.

\title{
The Role of Diet in Cancer Prevention and Chemotherapy Efficacy
}

\author{
Steven D. Mittelman \\ Division of Pediatric Endocrinology, UCLA Children's Discovery and Innovation Institute, David \\ Geffen School of Medicine UCLA, Los Angeles, CA
}

\begin{abstract}
Despite great strides that have been made in treatments, cancer remains a leading cause of death in much of the world. Diet is known to have large impacts on health in general, and caloric restriction and fasting have putative benefits for many diseases and even to prolong life. There are strong epidemiological associations between obesity and cancer, and healthy diets have been shown to reduce cancer risk. However, less is known about how diet might impact cancer once it has already been diagnosed, and particularly how diet can impact cancer treatment. In the present review, we will discuss the preclinical and epidemiological links between obesity, diet, and cancer. We will explore potential mechanisms by which diet can improve cancer treatment outcome, including hormonal, metabolic, and immune/inflammatory effects of diet, and present the limited clinical research that has been published in this arena. Despite the paucity of data, diet intervention may offer multiple benefits to cancer patients, including reduced toxicity, improved chemotherapy efficacy, and lower risk of long term complications. Thus, it is important that we understand the state of the science of dietary intervention to improve cancer treatment outcome, and expand our studies evaluating this important but complex adjunctive treatment strategy.
\end{abstract}

\section{Keywords}

Obesity; fasting; ketogenic diet; caloric restriction

Let food be thy medicine and medicine be thy food

--Hippocrates

Cancer treatment has improved tremendously over the past century. Childhood acute lymphoblastic leukemia has changed from a nearly uniformly fatal disease to one with a $\sim 90 \%$ cure rate. The five year survival rate from all cancers has increased from $49 \%$ in 1975 to $70 \%$ in 2011 (2), and there have been paradigm-shifting advances that are greatly improving treatment outcomes of many cancers, such as chronic myelogenous leukemia, metastatic melanoma, and Her2-positive breast cancer. Despite these advances, cancer remains a most feared diagnoses, driving many to seek out alternative treatments.

\footnotetext{
Corresponding Author: Steven D. Mittelman, MD, PhD, Division of Pediatric Endocrinology, UCLA Children's Discovery and Innovation Institute, David Geffen School of Medicine UCLA, 10833 Le Conte Ave, Los Angeles, CA, USA 90095-1752, smittelman@mednet.ucla.edu, Phone: 310-825-6244.

Conflict of Interest: The author declares no relevant conflict of interest
} 
We have long known that diet plays an important role in our health. It stands to reason that people would look to diet to provide for a sliver of hope for cancer patients. While it is well-established that obesity is associated with cancer incidence and mortality, the data linking specific nutrients and food items to cancer are sparse. Even more elusive are studies examining how diet can affect the treatment outcome of cancer once it has already been diagnosed.

In the present review, we will examine the evidence from preclinical and clinical studies on how diet can affect cancer outcome. Dietary restriction interventions target many of the hormones and pathways affected by obesity, and so understanding how obesity can worsen cancer treatment may yield clues as to how diet can help. We will discuss the role of diet in cancer incidence and progression, but focus primarily on the state of the science evaluating treatment efficacy.

\section{Epidemiology Cancer Incidence}

In 2003, Eugenia Calle and colleagues published a landmark study confirming the strong links between obesity and cancer mortality (27). In a prospective cohort of over 900,000 men and women in the U.S., the authors found that obesity increased the risk of dying from cancer of the esophagus, colon, liver, gallbladder, pancreas, and kidney, along with non-Hodgkin's lymphoma and multiple myeloma. They estimated that overweight and obesity were responsibly for $\sim 14 \%$ of cancer deaths in men and $20 \%$ of cancer deaths in women in the U.S. Many studies have confirmed these findings, in the U.S. and worldwide $(139,140)$. The World Cancer Research Fund and American Institute of Cancer Research's (WCRF/AICR) Continuous Update Project most recently concluded that there was convincing evidence that body fatness, variably defined by body mass index (BMI), waist circumference, or waist-to-hip ratio, increases the risk of esophageal, pancreatic, liver, colorectal, postmenopausal breast, endometrial, and kidney cancer (1). They also concluded a probable increased risk of fatness contributing to oropharyngeal, stomach, gallbladder, ovarian, and advanced prostate cancers.

Obesity is defined by a BMI $\geq 30 \mathrm{~kg} / \mathrm{m}^{2}$ ( $\geq 95^{\text {th }}$ percentile in youth), while overweight is a BMI $\geq 25 \mathrm{~kg} / \mathrm{m}^{2}$ ( $\geq 85^{\text {th }}$ percentile in youth). While most epidemiological studies examining cancer incidence and mortality have focused on obesity based on this anthropomorphic definition, others have examined its physiologic aspects. The metabolic syndrome describes the aggregation of obesity, dyslipidemia, and insulin resistance which tend to cluster in the obese, particularly those with visceral obesity. In contrast, the term "metabolically healthy obese" or sometimes colloquially, "fat fit", was coined to describe those who are physically obese, but show none of the metabolic sequelae. A prospective study of over 20,000 participants showed that metabolic health was the main contributor to cancer risk, and overweight and obesity per se did not increase the risk of cancer mortality in metabolically healthy individuals (4). Surprisingly, in metabolically unhealthy individuals, overweight and obesity appeared to offer somewhat of a protective effect. 
Diabetes has also been associated with risk of cancer incidence and mortality, though there is heterogeneity in the literature $(31,175)$. The vast majority of diabetes worldwide is type 2 diabetes, which is caused by a combination of insulin resistance and beta cell failure. Type 2 diabetes is strongly associated with obesity, which likely explains much of this correlation. However, some studies that adjust for BMI report an independent association between diabetes and cancer $(10,191)$.

Diet itself has been linked to cancer incidence, both in specific dietary components and overall calories. Hursting et al showed that leukemia incidence worldwide was strongly correlated with caloric intake (71). In a case-control study, caloric intake (from food frequency questionnaires) more than $20 \%$ below that expected from metabolic rate and activity estimates, reduced the risk of breast cancer in premenopausal (OR 0.36, p<0.001), but not postmenopausal women (98). Levine and colleagues found that high protein intake in people 50-65 years old was associated with a four-fold increased risk of cancer mortality (96). Red meat intake itself may be linked to breast cancer risk (183). However, metaanalyses have failed to identify negative impact of high protein intake on prostate, ovarian, colorectal, or renal cell cancer $(89,95,106,129)$.

The American Cancer Society and the WCRF/AICR have published dietary guidelines to prevent cancer $(1,84)$. Both sets of guidelines promote maintaining a healthy weight, being physically active, consuming fruits and vegetables, and limiting red meat and alcohol consumption. The WCRF/AICR guidelines further recommend decreasing intake of energy dense foods and salt and supporting breastfeeding. A recent meta-analysis including 10 large prospective cohorts showed that high adherence to either of these dietary guidelines was associated with a lower risk of overall, breast, colorectal, and endometrial cancer, compared to subjects with the lowest adherence (84). Since avoiding obesity is an inherent part of these guidelines, it is not clear from these studies whether diet per se can modulate the risk of developing cancer.

While obesity increases the incidence of many cancers, there is emerging evidence that weight loss can modulate this risk. Self-reported weight loss in postmenopausal women enrolled in the Women's Health Initiative was associated with a 29\% decreased risk of endometrial cancer (100). Bariatric surgery has been associated with a reduction in cancer incidence; a recent meta-analysis confirmed that bariatric surgery reduced the risk of cancer in morbidly obese people, though cautioned regarding the significant heterogeneity existing between studies (29).

\section{Cancer Outcome}

Most of the association between obesity and cancer mortality is based on the higher risk of being diagnosed with cancer. There is also evidence that obese patients, once diagnosed with cancer, have a poorer outcome than nonobese. Poorer outcome and increased mortality have been observed in obese patients following diagnosis of breast (34), colon (162), prostate (6), pancreatic (190), ovarian (187), and hematologic (127) cancers. While many reports support this conclusion, a recent systematic review concluded that few studies were designed to examine this relationship, and so warned caution in interpreting these results (131). Interestingly, obesity is associated with an improved outcome in patients with metastatic 
melanoma treated with targeted therapy or immunotherapy (112); no significant effect was observed in patients treated with chemotherapy. Thus, obesity generally increases one's risk of both developing cancer and not surviving after diagnosis for most, but not all cancers.

\section{Potential mechanisms linking obesity to cancer outcome}

Obesity is not a simple phenotype, but is associated with a number of physical, genetic, physiological, socioeconomic, and behavioral variables, many of which could contribute to these associations with cancer. Animal models provide evidence that the observed associations between obesity and cancer in humans is likely based in biology, and not exclusively behavioral, environmental, or genetic. Obesity increases the rate of cancer development and growth in most preclinical models of genetic cancer predisposition (60, $69,192)$, carcinogen $(69,159,196)$ and cancer implantation $(45,185,193)$. However, fewer studies have looked at how obesity can impair cancer treatment in preclinical models (14, $52,74)$. Uncovering the biologic mechanisms linking obesity to cancer may provide some clues to how to reverse these links.

\section{Pharmacokinetics (PK)}

One clear dilemma that oncologists face when treating obese patients is how much chemotherapy to use. Obesity can affect both the volume of distribution and clearance of chemotherapies, and yet few studies evaluate PK of drugs in obese subjects. We have recently shown that adipocytes metabolize and inactivate the chemotherapy, daunorubicin (155), which could especially impair treatment in patients with excess adipose tissue. The dosing of some drugs, such as vincristine, is arbitrarily capped, which could disproportionately affect obese patients. Clinicians may be reticent to prescribe large doses of chemotherapies by actual body weight, particularly in obese patients who may already be at higher risk of toxicities. Despite the paucity of data, the American Society of Clinical Oncology developed guidelines stating that chemotherapy should be dosed in obese adult patients based on actual weight (62).

\section{Inflammation}

Inflammation has long been known as a driver of cancer incidence, and indeed is considered a hallmark of cancer (66). Obesity itself is a state of subclinical inflammation. Though the mechanisms driving this state are not fully understood, they are likely driven in part by adipose tissue inflammation. A number of immune cells, including macrophages, B and $\mathrm{T}$ lymphocytes, natural killer (NK), and natural killer T (NKT) cells normally infiltrate adipose tissue. As obesity develops, these immune cells accumulate and take on proinflammatory states. Macrophages increase expression of TNFa and other proinflammatory cytokines (sometimes simplistically referred to as an "M1" state). They tend to accumulate around necrotic adipocytes, sometimes forming a "crown-like" structure. T lymphocyte numbers increase, particularly CD8+ T cells, along with B cells, mast cells, and NKT cells (8). Together, the interaction between these immune cells and the obese adipocytes contributes to local and systemic increases in a number of pro-inflammatory cytokines, including TNFa, IL-6, IL-1 $\beta$, and plasminogen activator inhibitor-1 (15). At the same time, levels of the 
anti-inflammatory signal, adiponectin are lower in the obese. Together this inflammatory milieu could contribute to increased carcinogenesis and/or impaired anti-cancer immunity.

In addition to systemic signals, local adipose tissue inflammation may promote the incidence of some cancers, as well as contribute to their aggressiveness and treatment resistance. Adipose tissue macrophages and crown-like structures in breast adipose tissue have been linked with breast cancer (117). Expansion of breast and colon cancer into adjacent adipose tissue is associated with local adipose tissue inflammation $(86,198)$ and potentially a poorer outcome (86). Whether this is a response to the tumor expansion, or a precursor is not clear, but clearly interactions between the inflamed adipose tissue and tumor cells can promote further infiltration and treatment resistance.

\section{Hormones}

Estrogen: Estrogens have long been known to increase cancer risk, particularly that of estrogen-sensitive tissues, such as breast and endometrium. Adipose tissue is a major source of estrogen, which it converts from circulating androgens via high expression of the aromatase enzyme, and thus obesity is associated with increased circulating estrogen concentrations. Interestingly, obesity is associated with a lower risk of premenopausal breast cancer and a higher risk of postmenopausal breast cancer. This could potentially be explained by the fact that estrogen levels after menopause would be more significantly higher in obese individuals than before menopause, when ovarian secretion dominates systemic levels.

Insulin: Obesity is strongly associated with insulin resistance, which leads to compensatory hyperinsulinemia. Insulin resistance primarily impacts the glucoregulatory effects of insulin, while its growth-promoting effects on protein synthesis and cell proliferation are relatively spared and therefore enhanced in the hyperinsulinemic state. Insulin receptor signaling involves several pathways implicated in cancer, including phosphoinositide 3kinase/protein kinase B (PI3K/AKT), mitogen-activated protein kinase (MAPK), signal transducer and activator of transcription (STAT), and extracellular signal-regulated kinase (ERK). Activation of these pathways can increase proliferation, prevent apoptosis, and are often associated with chemotherapy resistance. In addition, insulin inhibits the synthesis of sex hormone binding globulin, leading to an increased proportion of free, active estrogen in the circulation. Insulin also increases the production of insulin-like growth factor 1 (IGF-1; see below) Thus it is likely that insulin contributes to increased cancer incidence and poorer prognosis in obese individuals through a number of direct and indirect mechanisms.

IGF-1: IGF-1 is considered a major link between obesity and cancer. As its name implies, IGF-1 has similar effects on cells as insulin, stimulating PI3K/AKT and MAPK pathways. While total IGF-1 concentrations can be low or normal in obese, the free, active form of the hormone is generally elevated. IGF-1 has been shown to increases proliferation rate and cause chemotherapy resistance in a number of cancers $(65,97)$. People with Laron Syndrome have extremely low IGF-1 levels, and are protected from cancer (91), as are animal models of low IGF-1 $(134,138)$. 
Leptin: Leptin is secreted by adipocytes in proportion to obesity and whole-body adiposity (35). Despite this strong correlation with obesity, epidemiological studies have not found consistent links between leptin and cancer incidence $(64,188)$. The leptin receptor signals through Jak/Stat, and indirectly increases PI3K, mTOR, and AKT signaling, all of which could contribute to cancer cell progression. However, the data addressing this issue is mixed. Leptin receptor expression has been associated with improved outcome in leukemia $(85,99)$. However, leptin signaling, particularly through the Notch pathway, may be important for cancer stem cells, and blocking this pathway appears to improve outcome in in vivo models of pancreatic (67) and breast cancer (179).

Adiponectin: Adiponectin circulates at very high concentrations in blood, in inverse proportion to adiposity, and has overall positive effects on metabolism and inflammation. Adiponectin signals through the AMPK pathway, which can promote apoptosis in cancer cells (93), decrease angiogenesis, and limit tumor growth in animal models (see (36)). Thus, the lower circulating adiponectin level seen in obesity likely plays a permissive role in tumorigenesis and cancer treatment resistance.

\section{Metabolic Fuels}

Obesity is simplistically a disorder of increased nutrient availability, and thus is associated with a surfeit of stored and circulating fuels. As the metabolic syndrome develops into frank diabetes, systemic levels of glucose, triglycerides, and some amino acids increase. The three branched chain amino acids (BCAA), valine, leucine, and isoleucine, play an integral role in obesity and the metabolic syndrome. Since cancer cells have increased metabolic demands and altered metabolism, it is possible that increased availability of some of these fuels contributes to the risk and outcome of cancer in obesity.

\section{Microbiome}

Over the past two decades we have become more aware of how the microbiome affects nearly all aspects of our health. In particular, our microbiome can have large effects on our immunity and metabolome, both locally and systemically. Microbiota in the gut can produce butyrate, which has beneficial effects to reduce inflammation, as well as secondary bile acids, which can be carcinogenic (125); the balance of these types of beneficial and detrimental pathways can contribute to cancer risk. Obesity is associated with predictable changes in the intestinal microbiome, namely increased representation by firmicutes and lower prevalence of bacteroides, though this is oversimplification does not do justice to the vast and complex literature on this topic (see (109) for a recent review). There is some evidence that these microbiome changes are causal or at least reinforcing for the development or persistence of the obese state. With respect to cancer, there is evidence linking the obesity-associated microbiome and colorectal (125) and liver (189) cancers, though the data are not yet conclusive (61). The microbiome likely represents an important link between obesity and cancer, but the complexity of both obesity and the microbiome make teasing apart these effects difficult. 


\section{Covariates}

In addition to these mechanistic links, there are a host of covariates that undoubtedly contribute to the observed associations between obesity and cancer. It is not unreasonable to hypothesize that there may be genetic polymorphisms that can predispose to both obesity and cancer. While there are few specific polymorphisms that can explain a significant portion of obesity, FTO gene polymorphisms are fairly common, and in the $\sim 16 \%$ of people who are homozygous for the risk allele there is a 1.67 odds ratio of adult obesity (57). Recently, FTO polymorphisms have been linked to increased cancer risk, particularly leukemias and glioblastomas (41). There are likely a number of other genetic polymorphisms which contribute to obesity, and may also directly or indirectly increase the risk of cancer.

Given the higher prevalence of obesity in people of lower socioeconomic status (SES) and ethnic and racial minorities, it is important to consider the influence of these factors on cancer incidence and mortality. Lower SES plays a clear role in contributing to cancer mortality, such that poverty has been called a carcinogen (23). Lower SES can contribute to increased cancer risk and worse cancer outcome in a number of ways, including less access to preventive medicine and screening, increased risk behaviors, later presentation of disease, barriers to optimal treatment (181).

Race and ethnicity can also predispose to both obesity and cancer incidence/poor outcome, some of which is mediated by lower SES. Hispanics in the U.S. are at a much higher risk of obesity and type 2 diabetes. Overall, Hispanics tend to have a lower incidence of most cancers compared to non-Hispanic whites. However, stomach, gall bladder, liver, and cervical cancers are striking exceptions, with much higher incidence in Hispanics (113). The incidence of childhood acute lymphoblastic leukemia has been increasing over the past decade, which has been attributed to an increased prevalence in older Hispanic children (11). This association is compounded by the fact that Hispanic children have a worse survival from hematologic malignancies (80). The mechanisms behind these associations are as yet unknown, but could be mediated in part by dietary differences, predilection for obesity and insulin resistance, genetic polymorphisms, SES, or other cultural behavioral differences. Because the Hispanic ethnicity encompasses a wide range of people who appear to have differing susceptibilities to obesity, diabetes, and cancer, studies to tease apart these associations should consider and account for this variability.

Blacks males in the U.S. are at a higher risk of developing cancer and have a higher cancer mortality than non-Hispanic whites (158). Black women have been at a lower risk of breast cancer incidence, but when diagnosed are more likely to have more aggressive forms and worse outcomes (120). While much of this discrepancy appears to be due to presenting at a more advanced stage of disease, disparate health care, and higher health burden from other illnesses, even after adjusting for these there appears to be a modest cancer-specific survival difference (9). More work is needed to tease out the cultural, genetic, and SES differences in order to identify potential mechanisms behind these associations.

Finally, a number of behaviors could contribute to the relationships between obesity and cancer. Obese individuals may be more likely to be heavy drinkers (150), consume more 
red meat (145), and live near large roadways exposing them to air pollution (110), while eating less fiber (163) and foods containing antioxidants (70). Obese patients appear to be less likely to be screened for some cancers $(13,152)$, for a variety of reasons including physicians' discomfort in performing screening exams (55); this could result in obese patients presenting with cancer at a later stage.

\section{Specific Cancers}

In addition to the systemic and overarching influences described above, obesity has specific effects on many organs that can predispose them to cancer development and/or limit cancer treatment. Lipid accumulation in the liver, or nonalcoholic fatty liver disease (NAFLD), is common in obesity, particularly in the Hispanic population. NAFLD can progress to steatohepatitis (NASH), with an increasing degree of liver inflammation that develops. This likely explains the strong association between obesity and hepatocellular carcinoma (HCC); obese men were $\sim 4.5$ times more likely to die from liver cancer than controls (27). Given the higher prevalence of both obesity and obesity-related liver disease in Hispanics, it is not surprising that Hispanic ethnicity is associated with an increased risk of developing HCC.

Esophageal carcinoma is known to be related to chronic gastroesophageal reflux. Reflux of the acidic stomach contents can cause irritation and inflammation in the inferior esophagus, eventually leading to metaplasia and premalignant changes, termed Barrett's esophagus. Obese individuals are at a higher risk of suffering from reflux (OR 1.73), Barrett's esophagus (OR 1.24), and esophageal adenocarcinoma (OR 2.45; see (142)). These associations are likely primarily due to increased abdominal pressure, though confounding effects of specific dietary components have not been ruled out.

Obese individuals are about twice as likely as to die from pancreatic cancer compared to lean (27). Since mortality from pancreatic cancer so high, this association is undoubtedly driven by increased incidence, though BMI at diagnosis also predicts survival (190). Obesity is a strong risk factor for pancreatitis, mediated in part by increased prevalence of diabetes, gallstones, and hypertriglyceridemia (81), and pancreatitis is itself a major risk factor for pancreatic cancer. However, chronic pancreatitis accounts for only a few percent of pancreatic cancer patients (48), and so obesity much have additional effects independent of pancreatitis.

\section{Cancer Metabolism}

To understand how diet can affect cancer treatment and prognosis, it is important to understand some of the unique aspects of cancer metabolism. In 1925, Otto Warburg observed that cancerous tumors take up more glucose than other tissues, and metabolize it without relying on oxidative phosphorylation, called the Warburg effect (180). Although aerobic glycolysis does not provide as much ATP as oxidative phosphorylation, it is believed to better support cancer cell metabolism for a number of reasons. First, tumors can grow rapidly, sometimes outpacing their blood supply, leading to a relatively hypoxic environment. Second, the metabolic machinery needed to perform glycolysis is much less extensive than oxidative phosphorylation, being independent of mitochondria. Third, 
carbon atoms from glucose can be used to synthesize amino acids, nucleic acids, and other metabolic intermediates in a process of anapleurosis.

Our understanding of the Warburg effect has significantly evolved over the last century. It was shown that many cancer cells do have high respiratory rates, arguing against their reliance on aerobic metabolism (184). The Lisanti group demonstrated that cancer cells induce stromal cells in their microenvironment to shift to aerobic metabolism, inducing them to release lactate and pyruvate which are used by the cancer cells for oxidative metabolism (132). This "Reverse Warburg Effect" could result in overall increased glucose uptake and aerobic metabolism in a tumor, but mostly due to the stromal cells.

In addition to increased glucose utilization, cancer cells often exhibit a dependence on free fatty acids (FFA). FFA provide the acyl chains of phospholipids, the primary component of cell and organelle lipid bilayer membranes. Since a dividing cell duplicates its plasma membranes with every division, a large investment in FFA is required for a cancer cell to proliferate. FFA synthesis is energetically expensive, utilizing 14 NADPH and 7 ATP to synthesize one molecule of palmitate. Increased de novo FFA synthesis and exogenous FFA uptake have both been associated with cancer aggressiveness and survival $(87,121,126$, 149). On the other hand, FFA can provide a large amount of energy, and are often abundant in tumor microenvironments, particularly those in proximity to adipocytes. Thus, cancer cells in adipocyte-rich environments have been shown to rely heavily on FFA oxidation $(122,168)$.

Adipocytes can also be a source of amino acids. We have shown that adipocyte release of glutamine and asparagine can particularly interfere with acute lymphoblastic leukemia treatment with L-asparaginase (52). Glutamine is also extremely important for other cancer cells, where it contributes to the synthesis of nucleotides, amino acids, and TCA cycle intermediates (195). Cancer cells use BCAAs for protein synthesis and energy metabolism, and often overexpress branched chain aminotransferase enzymes needed for BCAA metabolism (7). Thus, cancer cells exhibit unique metabolic needs which may be met in obese, adipose rich environments.

\section{Weight changes during cancer treatment}

During the development of cancer, and over the course of its treatment, the body can exhibit dramatic changes in weight and composition. Many cancers are associated with cachexia, which encompasses weight loss disproportionately affecting lean body mass. Cachexia is generally attributed to inflammatory cytokines associated with cancer burden, such as TNFa, IL-6, and IL-1a; however, anorexia can be exacerbated by pain, depression, and nausea associated with the diagnosis of cancer and its treatments. Weight loss associated with cachexia is generally considered a poor prognostic sign. Cancer cachexia could be a marker of a more aggressive or advanced cancer, or a more toxic response to treatment. Alternatively (or additionally), the unhealthy weight loss associated with cachexia could somehow impair cancer treatment outcome. 
On the other hand, significant weight gain can occur over the course of some cancers. Cancers that are treated with high doses of glucocorticoids, particularly hematologic cancers, are associated with an increase in adiposity due to the adipogenic effects of these agents. We showed that BMI was not an accurate measure of obesity in adolescents during treatment for high-risk acute lymphoblastic leukemia (ALL); over the first month of treatment, subjects gained $\sim 1.5 \mathrm{~kg}$ of body fat and lost $6 \mathrm{~kg}$ of lean mass, resulting in a substantially higher body fat percentage (128). Thus, weight and BMI were not helpful in distinguishing these changes in body fat, such that even those who lost weight generally developed "sarcopenic obesity". This risk for excess adiposity and obesity persists throughout treatment for ALL, and indeed childhood cancer survivors are at more than a 4 fold risk of metabolic syndrome (54), including obesity, hypertension, dyslipidemia, and insulin resistance (124).

The bone marrow environment also undergoes drastic changes during chemotherapy treatment. Most chemotherapeutic agents are toxic to hematopoietic cells, leading to a drastic reduction in marrow space filled by hematopoietic cells. Much of this space becomes occupied by adipocytes, through unclear mechanisms. Steroid treatments used in some cancers exacerbate this, and the bone marrow in the iliac crest and long bones can be transformed into predominantly fat tissue. These fat cells may play a role in supporting hematologic and other cancers which reside in or metastasize to the marrow.

\section{Diet interventions}

Given the associations between obesity and poor cancer outcomes, the observation that cancer cells are excessive users of metabolic fuels such as glucose, amino acids, and fats, and the strong desire of patients, families, and practitioners to offer further hope, it is not surprising that dietary intervention has been a popular topic of discussion in the cancer treatment world. If proven beneficial to therapeutic efficacy, dietary interventions could lead to improved outcomes with little or no additional toxicity. Indeed, some data show that diet interventions could potential reduce chemotherapy side effects. Unfortunately, the vast majority of the discourse has been based on opinion and anecdotal evidence, and there is a paucity of scientifically validated diet interventions to offer cancer patients. We summarize below the preclinical and clinical evidence related to the most common diet interventions proposed for cancer patients.

\section{Fasting}

Fasting has been touted for its health benefits for decades. Epidemiological studies show improved lifespan, and reduced incidence of cancer and cardiovascular disease in people who practice intermittent fasting for religious or personal reasons. Fasting has been tested in several preclinical models of cancer initiation/progression, with mixed results. Generally, studies have used intermittent fasting, which describes one or more fasting sessions that last for 24 or more hours. A meta-analysis evaluating the literature between 1994 and 2014 identified eight preclinical studies of intermittent fasting and cancer, five of which identified a benefit of intermittent fasting and three of which did not (102). Studies which have looked at the impact of fasting on the growth of implanted cancer cells in mice have found 
beneficial effects in some models $(17,26,94,99,107,148,166)$, but not others $(24,39,88$, $94,99,137,170)$, some even finding beneficial effects on one cancer but not another (94, 99) indicating that fasting could potentially have cancer-specific effects. About two thirds of these cancer models using immunocompetent mice identified beneficial effects of fasting ( 9 out of 14), while only half using immunocompromised models concluded a positive effect (4 of 8). This variability might imply that the beneficial effects of fasting on cancer progression/treatment efficacy require an intact immune system. Indeed, fasting has been shown to prevent and reduce autoimmunity (32). One study showed that fasting reduced the accumulation of tumor associated macrophages (TAMs), consistent with an immune system mediated benefit (166). A few studies have examined the effects of fasting on spontaneous tumor onset/progression of cancer in either genetic or carcinogenic models of cancer, with most identifying a beneficial effect of fasting on tumor incidence $(16,51,143,172)$.

Whether fasting can improve cancer treatment outcome has also been tested in several preclinical studies (Table 1). Most studied found synergistic effects of fasting on anticancer therapy, including radiation and chemotherapies, though there were several exceptions to this. In addition to cancer progression and treatment efficacy, there may be a role of fasting to reduce treatment toxicities. Fasting has been shown to protect mice from toxicity induced by etoposide (137), irinotecan (78), doxorubicin (22), and abdominal radiation (39).

There are few clinical studies testing fasting on therapeutic outcome. A case series by Safdie et al. demonstrated that complete fasting, from 36-140 hours before and 8-56 hours after chemotherapy is feasible in adult patients with solid tumors (147). These were complete fasts, with the exception of water and sometimes vitamins, and were associated with subjective reduction in chemotherapy side effects and no clear evidence of impaired chemotherapy efficacy. Short term fasting was tested in a randomized study of 13 patients receiving neo-adjuvant treatment for breast cancer. Fasting for 24 hours before and after chemotherapy was well-tolerated in the seven patients randomized to fast, and subjects exhibited higher red cell and white cell counts after chemotherapy compared to the nonfasted groups (38). Further confirming the feasibility of fasting in cancer patients, Dorff et al. prescribed escalating "doses" of fasting in consecutive subgroups, increasing from 24 hours before treatment to 48 hours before and 24 hours after treatment (46). Twenty subjects with a variety of cancers being treated with platinum-based therapies were enrolled. Of these, 13 were considered compliant with the intervention, consuming $<200$ $\mathrm{kCal} / \mathrm{day}$. Fasting-related symptoms were generally mild, and there were no grade 3 or 4 fasting-related toxicities. In another study, 34 patients being treated for breast or ovarian cancer were randomized in a crossover design to receive short term fasting during the first or second half of their planned chemotherapies, versus ad lib diet during the other half. Fasting lasted 60 hours total ( 36 hours before and 24 hours after chemotherapy), and showed some efficacy in improving quality of life and reducing fatigue, though effect on chemotherapy efficacy was not evaluated (12).

\section{Calorie restriction}

While periods of complete fasting are likely to induce the most drastic metabolic shifts, this might not be feasible or acceptable to all patients, and so alternative approaches have 
been explored. Caloric restriction may provide some of the same benefits as fasting through similar mechanisms. Caloric restriction can also be imposed for longer periods of time, and thus could conceivably provide more sustained benefits. There have been many preclinical studies evaluating the effects of caloric restriction on cancer initiation and progression, again with a high degree of variability between cancer models, diet interventions, and outcomes evaluated. A majority of studies limit calories by reduction of carbohydrates, though some include protein limitation or proportional limitation of all nutrients. When diet is imposed as a chronic condition, animals are generally provided between $60 \%$ and $85 \%$ of what an ad libitum (AL) control would consume. Intermittent strategies involve more severe caloric restriction, generally $50-67 \%$ of AL for 1-3 week discrete periods. These restriction periods alternate with periods of either full AL consumption, or consumption matched to an $\mathrm{AL}$ group (to prevent compensatory overeating during nonfasting periods). Thus, it can be difficult to compare studies that use different calorie restriction regimens.

Despite the variability in regimens, there is convincing evidence that calorie restriction can delay cancer in spontaneous and carcinogenesis models (16, 19-21, 28, 33, 42, 44, 47, $50,53,59,63,72,73,75,76,90,92,104,105,114-116,135,144,156,165,167,171$, $173,178,186)$ as well as transplant in syngeneic $(25,40,49,68,123,133,153,154,177)$ and xenograft models $(58,77,92,103)$. Only a minority of studies found no effect or a negative effect of caloric restriction $(18,22,79,88,111,130,169,174)$. A handful of studies have tested whether calorie restriction can improve treatment efficacy (Table 2). Our group showed that switching mice from a high-fat to a low-fat diet improved the treatment efficacy of vincristine against syngeneic B-cell ALL; however, we observed no synergy with dexamethasone or L-asparaginase (176).

\section{Carbohydrate restriction/ketogenic diet}

There has been great interest in using a ketogenic diet as an alternative to fasting and caloric restriction. A ketogenic diet could be better tolerated in some patients, and it has a long safety record as a treatment for epilepsy. A recent meta-analysis identified 12 studies which tested unrestricted ketogenic diet against standard diet in murine cancer models, and concluded an overall growth delay with the ketogenic diet (83). A few studies have evaluated a ketogenic diet during anti-cancer treatment, reporting synergy in most cases with irradiation, metformin, and chemotherapy (Table 3).

A recent systematic review identified six articles describing clinical intervention with a ketogenic diet in pediatric or adult patients with glioma, together including 39 subjects, along with 12 ongoing trials (108). While none of the published studies were randomized control trials, the results showed that a ketogenic diet could be well-tolerated with few adverse effects, and may confer some benefit to overall and progression free survival, though the case-series study designs without comparisons to control groups preclude more definitive conclusions.

\section{Other diet interventions}

There have been a number of diets that don't fit into the above categories that may provide beneficial effects on cancer risk and outcome. Strict adherence to a Mediterranean diet has 
been associated with reduced all-cause cancer mortality, as well as mortality from breast, colorectal, head and neck, gastric, prostate, liver, respiratory and pancreatic cancers (151). Olive oil, a major component of the Mediterranean diet, contains high concentrations of MUFA, antioxidants, and other potentially beneficial components. People in the highest category of olive oil consumption exhibited a lower odds of overall cancer, as well as breast and gastrointestinal cancers (136). Protein restriction can reduce the growth of human xenograft breast and prostate cancer (56), though low animal protein intake was not associated with cancer mortality in prospective cohorts (164). A meta-analysis including 96 cohort and cross-sectional studies concluded that vegetarian and vegan diets reduced the incidence of cancer, by $\sim 8 \%$ and $15 \%$ respectively (43). Further, higher intake of vegetable vs. animal fats after diagnosis of prostate cancer was associated with an improved survival (141). In a meta-analysis, increased soy intake was associated with a decrease risk of breast mortality and recurrence (157). There have been numerous studies evaluating specific dietary components for anti-cancer effects in vitro and preclinical models (for example (114), (51)). However, there are no studies to our knowledge examining whether any of these diets or dietary components can improve chemotherapy treatment outcomes.

\section{Mechanisms}

The above diets induce a host of metabolic effects, many of which can be beneficial for a patient during cancer treatment. With caloric restriction and fasting, systemic levels of glucose and some lipids and amino acids decrease, limiting the available fuel for cancer cells to grow and divide. Ketogenic diets could exert additional anti-cancer effects through toxicity of ketones themselves. Indeed, ketogenic diet efficacy may be reversed in tumors which express high levels of ketone metabolizing enzymes (194).

A primary hypothesis on how fasting, and potentially caloric restriction, work is termed "differential stress" (137). Upon fasting, levels of many anabolic hormones drop, including insulin, IGF-1, and leptin. Combined with reduced metabolic fuel availability, these changes reduce anabolic signaling in non-cancerous cells, leading to increased mTOR and decreased AKT. These signals slow cell growth and proliferation, and can induce autophagy, all of which would tend to make healthy cells less susceptible to chemotherapies-particularly those that target dividing cells. On the other hand, one of the hallmarks of cancer cells is growth and proliferation independent of local and systemic signals; thus, fasting may not alter proliferation rates of these cells, which would therefore retain susceptibility to chemotherapy. In addition, the decrease in availability of fuels, including glucose, lipids, and amino acids, can have additional detrimental effects on cancer cells, which may not exhibit the same metabolic flexibility of host cells. Thus, rapid proliferation in the face of fuel deprivation may induce oxidative stress, increasing the likelihood of DNA replication errors and catastrophic mitotic events. Together these effects should widen the therapeutic window between host and cancer cells, and allow a more targeted killing of cancer by chemotherapy.

Hormonal changes induced by diet interventions can have additional effects as well. Some cancer cells are sensitive to growth promoting hormones such as insulin and IGF-1, and may become more sensitive to chemotherapy once these signals are reduced by dietary intervention. This effect was demonstrated by Dunn et al., who showed that replacement of 
IGF-1 reversed the survival benefit observed during dietary restriction (50). Alternatively, caloric restriction and fasting cause adiponectin levels to rise, which could theoretically promote apoptosis in cancer cells. Other hormonal effects might be more complicated; Lu et al. elegantly showed that leukemia cells in obese mice were resistant to leptin, but upon fasting would increase expression of leptin receptors, leading to leukemia cell differentiation and improved mouse survival (99).

It is likely that dietary interventions have multiple effects on the host environment which can impact cancer progression and sensitivity to treatment. An energy restricted diet can reduce inflammatory monocyte populations in overweight and obese adults within 16 weeks (82). A ketogenic diet was shown to enhance anti-tumor immunity, increasing CD4+ non T-reg tumor infiltration (101). Importantly, the beneficial effects of the diet were reversed with CD8+ T-cell depletion. Diet interventions have major effects on the microbiome, which can in turn alter inflammation, the systemic metabolome, and even potentially chemotherapy metabolism (146). Dietary restriction can reduce vascularization, potentially limiting tumor oxygen and nutrient access (171). These and other beneficial effects of diet intervention could potentially provide additive benefits to cancer treatment.

\section{Which is the best diet?}

While much can be learned about obesity, diet and cancer outcome from preclinical studies, it is important to keep in mind that mice are not humans. The most common mouse model of obesity, the diet-induced obese C57BL/6 mouse, gets obese on a diet consisting of 45\% or $60 \%$ of calories from fat. This is in contradistinction to humans, whose obesity is thought to be more related to excess carbohydrates. Few studies have tested multiple diets in a head-to-head fashion, and even in those, the "winning" diet may be better simply due to specifics of the models chosen. For example, caloric restriction at $60 \%$ of ad libitum showed a better survival benefit in p53 heterozygous mice than fasting one day per week (16). But what if they had tested fasting two days per week, or every other day? A 60-hour fast was more effective than $50 \%$ caloric restriction in protecting mice from doxorubicin toxicity (22), but what if it was less effective in synergizing with its anti-cancer activity? Or with the activity of a different chemotherapy? It is difficult if not impossible to make "fair" diet comparisons in these types of studies because matching caloric intake does not necessarily match tolerability. Further, diets may act differently in different cancer models, varying by cancer type, stage, mutations, species, treatment regimen, etc. A recent meta-analysis compared the efficacy of chronic vs. intermittent caloric restriction, and found that intermittent calorie restriction was more effective in reducing the incidence of cancer in genetically engineered models, while chronic calorie restriction was better for carcinogen models (30). It is difficult to translate these results into clinical recommendations.

A systematic review and meta-analysis including many of the above studies compared the efficacy of caloric restriction, ketogenic diet, and intermittent fasting on cancer initiation, progression, and metastasis (102); the authors concluded that caloric restriction and ketogenic diet were highly effective, while the data on intermittent fasting were not yet conclusive. Given the paucity of data examining dietary intervention during 
cancer treatment, particularly in patients, more work will need to be done to test which interventions have the best efficacy against specific cancers.

\section{Summary/Conclusions}

It is clear that our diet has a major impact on our cancer risk. The preclinical literature strongly supports the potential of diet intervention to improve cancer treatment outcomes. It is not possible to determine at this point which dietary strategy is the best, and it is likely that diet efficacies will vary based on patient, cancer types, and treatment regimen. Clinicians who care for overweight and obese patients know that sometimes the best diet is the one that the patient is willing and able to adhere to, and so a degree of personalization may be needed when instituting these strategies into the clinic. Unfortunately, this requires flexibility, ancillary support staff, and an understanding that a lifestyle intervention may have efficacy on par with cytotoxic agents.

While translating these findings from mice to patients is not straightforward, it is imperative that we continue to explore this avenue. Diet intervention has the potential to improve cancer outcome without introducing additional toxicities and long-term complications. Indeed, most evidence points to diet intervention as reducing toxicity, and thereby facilitating more effective chemotherapy. Integrating this shift in paradigm into oncology will require more clinical trials and time.

\section{Funding:}

SDM is funded by R01CA201444 and R01213129 from the National Cancer Institute

\section{References}

1. World Cancer Research Fund/American Institute for Cancer Research. Diet, Nutrition, Physical Activity and Cancer: a Global Perspective. Continuous Update Project Expert Report 2018. Available at dietandcancerreport.org

2. 2018. Surveillance,Epidemiology,and End Results (SEER) Program (www.seer.cancer.gov) SEER*Stat Database.

3. Abdelwahab MG, Fenton KE, Preul MC, Rho JM, Lynch A, et al. 2012. The ketogenic diet is an effective adjuvant to radiation therapy for the treatment of malignant glioma. PLoS One 7: e36197 [PubMed: 22563484]

4. Akinyemiju T, Moore JX, Pisu M, Judd SE, Goodman M, et al. 2018. A Prospective Study of Obesity, Metabolic Health, and Cancer Mortality. Obesity (Silver Spring) 26: 193-201 [PubMed: 29178569]

5. Allen BG, Bhatia SK, Buatti JM, Brandt KE, Lindholm KE, et al. 2013. Ketogenic diets enhance oxidative stress and radio-chemo-therapy responses in lung cancer xenografts. Clin Cancer Res 19: 3905-13 [PubMed: 23743570]

6. Allott EH, Masko EM, Freedland SJ. 2013. Obesity and prostate cancer: weighing the evidence. Eur Urol 63: 800-9 [PubMed: 23219374]

7. Ananieva EA, Wilkinson AC. 2018. Branched-chain amino acid metabolism in cancer. Curr Opin Clin Nutr Metab Care 21: 64-70 [PubMed: 29211698]

8. Anderson EK, Gutierrez DA, Hasty AH. 2010. Adipose tissue recruitment of leukocytes. Current opinion in lipidology 21: 172-77 [PubMed: 20410821]

9. Bach PB, Schrag D, Brawley OW, Galaznik A, Yakren S, Begg CB. 2002. Survival of blacks and whites after a cancer diagnosis. JAMA 287: 2106-13 [PubMed: 11966385] 
10. Bao C, Yang X, Xu W, Luo H, Xu Z, et al. 2013. Diabetes mellitus and incidence and mortality of kidney cancer: a meta-analysis. J Diabetes Complications 27: 357-64 [PubMed: 23433629]

11. Barrington-Trimis JL, Cockburn M, Metayer C, Gauderman WJ, Wiemels J, McKean-Cowdin R. 2017. Trends in childhood leukemia incidence over two decades from 1992 to 2013. Int J Cancer 140: 1000-08 [PubMed: 27778348]

12. Bauersfeld SP, Kessler CS, Wischnewsky M, Jaensch A, Steckhan N, et al. 2018. The effects of short-term fasting on quality of life and tolerance to chemotherapy in patients with breast and ovarian cancer: a randomized cross-over pilot study. BMC Cancer 18: 476 [PubMed: 29699509]

13. Beeken RJ, Wilson R, McDonald L, Wardle J. 2014. Body mass index and cancer screening: findings from the English Longitudinal Study of Ageing. J Med Screen 21: 76-81 [PubMed: 24756474]

14. Behan JW, Yun JP, Proektor MP, Ehsanipour EA, Arutyunyan A, et al. 2009. Adipocytes impair leukemia treatment in mice. Cancer Res 69: 7867-74 [PubMed: 19773440]

15. Berg AH, Scherer PE. 2005. Adipose tissue, inflammation, and cardiovascular disease. Circ Res 96: 939-49 [PubMed: 15890981]

16. Berrigan D, Perkins SN, Haines DC, Hursting SD. 2002. Adult-onset calorie restriction and fasting delay spontaneous tumorigenesis in p53-deficient mice. Carcinogenesis 23: 817-22 [PubMed: 12016155]

17. Bianchi G, Martella R, Ravera S, Marini C, Capitanio S, et al. 2015. Fasting induces anti-Warburg effect that increases respiration but reduces ATP-synthesis to promote apoptosis in colon cancer models. Oncotarget 6: 11806-19 [PubMed: 25909219]

18. Birt DF, Pour PM, Nagel DL, Barnett T, Blackwood D, Duysen E. 1997. Dietary energy restriction does not inhibit pancreatic carcinogenesis by N-nitrosobis-2-(oxopropyl)amine in the Syrian hamster. Carcinogenesis 18: 2107-11 [PubMed: 9395209]

19. Blando J, Moore T, Hursting S, Jiang G, Saha A, et al. 2011. Dietary energy balance modulates prostate cancer progression in Hi-Myc mice. Cancer Prev Res (Phila) 4: 2002-14 [PubMed: 21952584]

20. Boileau TW, Liao Z, Kim S, Lemeshow S, Erdman JW Jr., Clinton SK. 2003. Prostate carcinogenesis in N-methyl-N-nitrosourea (NMU)-testosterone-treated rats fed tomato powder, lycopene, or energy-restricted diets. J Natl Cancer Inst 95: 1578-86 [PubMed: 14600090]

21. Bonorden MJ, Rogozina OP, Kluczny CM, Grossmann ME, Grambsch PL, et al. 2009. Intermittent calorie restriction delays prostate tumor detection and increases survival time in TRAMP mice. Nutr Cancer 61: 265-75 [PubMed: 19235043]

22. Brandhorst S, Wei M, Hwang S, Morgan TE, Longo VD. 2013. Short-term calorie and protein restriction provide partial protection from chemotoxicity but do not delay glioma progression. Exp Gerontol 48: 1120-8 [PubMed: 23454633]

23. Broder S 1991. PROGRESS AND CHALLENGES IN THE NATIONAL CANCER PROGRAM. 27-33 pp.

24. Buschemeyer WC 3rd, Klink JC, Mavropoulos JC, Poulton SH, Demark-Wahnefried W, et al. 2010. Effect of intermittent fasting with or without caloric restriction on prostate cancer growth and survival in SCID mice. Prostate 70: 1037-43 [PubMed: 20166128]

25. Cadoni E, Marongiu F, Fanti M, Serra M, Laconi E. 2017. Caloric restriction delays early phases of carcinogenesis via effects on the tissue microenvironment. Oncotarget 8: 36020-32 [PubMed: 28415598]

26. Caffa I, D’Agostino V, Damonte P, Soncini D, Cea M, et al. 2015. Fasting potentiates the anticancer activity of tyrosine kinase inhibitors by strengthening MAPK signaling inhibition. Oncotarget 6: 11820-32 [PubMed: 25909220]

27. Calle EE, Rodriguez C, Walker-Thurmond K, Thun MJ. 2003. Overweight, obesity, and mortality from cancer in a prospectively studied cohort of U.S. adults. New England Journal of Medicine 348: $1625-38$

28. Carver DK, Barnes HJ, Anderson KE, Petitte JN, Whitaker R, et al. 2011. Reduction of ovarian and oviductal cancers in calorie-restricted laying chickens. Cancer Prev Res (Phila) 4: 562-7 [PubMed: 21325563] 
29. Casagrande DS, Rosa DD, Umpierre D, Sarmento RA, Rodrigues CG, Schaan BD. 2014. Incidence of cancer following bariatric surgery: systematic review and meta-analysis. Obes Surg 24: 1499_ 509 [PubMed: 24817500]

30. Chen Y, Ling L, Su G, Han M, Fan X, et al. 2016. Effect of Intermittent versus Chronic Calorie Restriction on Tumor Incidence: A Systematic Review and Meta-Analysis of Animal Studies. Sci Rep 6: 33739 [PubMed: 27653140]

31. Chen Y, Wu F, Saito E, Lin Y, Song M, et al. 2017. Association between type 2 diabetes and risk of cancer mortality: a pooled analysis of over 771,000 individuals in the Asia Cohort Consortium. Diabetologia 60: 1022-32 [PubMed: 28265721]

32. Choi IY, Lee C, Longo VD. 2017. Nutrition and fasting mimicking diets in the prevention and treatment of autoimmune diseases and immunosenescence. Mol Cell Endocrinol 455: 4-12 [PubMed: 28137612]

33. Cleary MP, Hu X, Grossmann ME, Juneja SC, Dogan S, et al. 2007. Prevention of mammary tumorigenesis by intermittent caloric restriction: does caloric intake during refeeding modulate the response? Exp Biol Med (Maywood) 232: 70-80 [PubMed: 17202587]

34. Conroy SM, Maskarinec G, Wilkens LR, White KK, Henderson BE, Kolonel LN. 2011. Obesity and breast cancer survival in ethnically diverse postmenopausal women: the Multiethnic Cohort Study. Breast Cancer Res Treat 129: 565-74 [PubMed: 21499688]

35. Considine RV, Sinha MK, Heiman ML, Kriauciunas A, Stephens TW, et al. 1996. Serum immunoreactive-leptin concentrations in normal-weight and obese humans. N Engl J Med 334: 292-5 [PubMed: 8532024]

36. Dalamaga M, Diakopoulos KN, Mantzoros CS. 2012. The role of adiponectin in cancer: a review of current evidence. Endocr Rev 33: 547-94 [PubMed: 22547160]

37. Dang MT, Wehrli S, Dang CV, Curran T. 2015. The Ketogenic Diet Does Not Affect Growth of Hedgehog Pathway Medulloblastoma in Mice. PLoS One 10: e0133633 [PubMed: 26192445]

38. de Groot S, Vreeswijk MP, Welters MJ, Gravesteijn G, Boei JJ, et al. 2015. The effects of short-term fasting on tolerance to (neo) adjuvant chemotherapy in HER2-negative breast cancer patients: a randomized pilot study. BMC Cancer 15: 652 [PubMed: 26438237]

39. de la Cruz Bonilla M, Stemler KM, Jeter-Jones S, Fujimoto TN, Molkentine J, et al. 2019. Fasting Reduces Intestinal Radiotoxicity, Enabling Dose-Escalated Radiation Therapy for Pancreatic Cancer. Int J Radiat Oncol Biol Phys 105: 537-47 [PubMed: 31271824]

40. De Lorenzo MS, Baljinnyam E, Vatner DE, Abarzua P, Vatner SF, Rabson AB. 2011. Caloric restriction reduces growth of mammary tumors and metastases. Carcinogenesis 32: 1381-7 [PubMed: 21665891]

41. Deng X, Su R, Stanford S, Chen J. 2018. Critical Enzymatic Functions of FTO in Obesity and Cancer. Front Endocrinol (Lausanne) 9: 396 [PubMed: 30105001]

42. Diaz-Ruiz A, Di Francesco A, Carboneau BA, Levan SR, Pearson KJ, et al. 2019. Benefits of Caloric Restriction in Longevity and Chemical-Induced Tumorigenesis Are Transmitted Independent of NQO1. J Gerontol A Biol Sci Med Sci 74: 155-62 [PubMed: 29733330]

43. Dinu M, Abbate R, Gensini GF, Casini A, Sofi F. 2017. Vegetarian, vegan diets and multiple health outcomes: A systematic review with meta-analysis of observational studies. Crit Rev Food Sci Nutr 57: 3640-49 [PubMed: 26853923]

44. Dogan S, Rogozina OP, Lokshin AE, Grande JP, Cleary MP. 2010. Effects of chronic vs. intermittent calorie restriction on mammary tumor incidence and serum adiponectin and leptin levels in MMTV-TGF-alpha mice at different ages. Oncol Lett 1: 167-76 [PubMed: 22966277]

45. Dong L, Yuan Y, Opansky C, Chen Y, Aguilera-Barrantes I, et al. 2017. Diet-induced obesity links to ER positive breast cancer progression via LPA/PKD-1-CD36 signaling-mediated microvascular remodeling. Oncotarget 8: 22550-62 [PubMed: 28186980]

46. Dorff TB, Groshen S, Garcia A, Shah M, Tsao-Wei D, et al. 2016. Safety and feasibility of fasting in combination with platinum-based chemotherapy. BMC Cancer 16: 360 [PubMed: 27282289]

47. Duan T, Sun W, Zhang M, Ge J, He Y, et al. 2017. Dietary restriction protects against diethylnitrosamine-induced hepatocellular tumorigenesis by restoring the disturbed gene expression profile. Sci Rep 7: 43745 [PubMed: 28262799] 
48. Duell EJ, Lucenteforte E, Olson SH, Bracci PM, Li D, et al. 2012. Pancreatitis and pancreatic cancer risk: a pooled analysis in the International Pancreatic Cancer Case-Control Consortium (PanC4). Ann Oncol 23: 2964-70 [PubMed: 22767586]

49. Dunlap SM, Chiao LJ, Nogueira L, Usary J, Perou CM, et al. 2012. Dietary energy balance modulates epithelial-to-mesenchymal transition and tumor progression in murine claudin-low and basal-like mammary tumor models. Cancer Prev Res (Phila) 5: 930-42 [PubMed: 22588949]

50. Dunn SE, Kari FW, French J, Leininger JR, Travlos G, et al. 1997. Dietary restriction reduces insulin-like growth factor I levels, which modulates apoptosis, cell proliferation, and tumor progression in p53-deficient mice. Cancer Res 57: 4667-72 [PubMed: 9354418]

51. E S, Yamamoto K, Sakamoto Y, Mizowaki Y, Iwagaki Y, et al. 2017. Intake of mulberry 1-deoxynojirimycin prevents colorectal cancer in mice. J Clin Biochem Nutr 61: 47-52 [PubMed: 28751809]

52. Ehsanipour EA, Sheng X, Behan JW, Wang X, Butturini A, et al. 2013. Adipocytes Cause Leukemia Cell Resistance to L-Asparaginase via Release of Glutamine. Cancer Res 73: 29983006 [PubMed: 23585457]

53. Engelman RW, Day NK, Good RA. 1994. Calorie intake during mammary development influences cancer risk: lasting inhibition of $\mathrm{C} 3 \mathrm{H} / \mathrm{HeOu}$ mammary tumorigenesis by peripubertal calorie restriction. Cancer Res 54: 5724-30 [PubMed: 7923222]

54. Faienza MF, Delvecchio M, Giordano P, Cavallo L, Grano M, et al. 2015. Metabolic syndrome in childhood leukemia survivors: a meta-analysis. Endocrine 49: 353-60 [PubMed: 25154516]

55. Ferrante JM, Fyffe DC, Vega ML, Piasecki AK, Ohman-Strickland PA, Crabtree BF. 2010. Family physicians' barriers to cancer screening in extremely obese patients. Obesity (Silver Spring) 18: 1153-9 [PubMed: 20019676]

56. Fontana L, Adelaiye RM, Rastelli AL, Miles KM, Ciamporcero E, et al. 2013. Dietary protein restriction inhibits tumor growth in human xenograft models. Oncotarget 4: 2451-61 [PubMed: 24353195]

57. Frayling TM, Timpson NJ, Weedon MN, Zeggini E, Freathy RM, et al. 2007. A common variant in the FTO gene is associated with body mass index and predisposes to childhood and adult obesity. Science 316: 889-94 [PubMed: 17434869]

58. Galet C, Gray A, Said JW, Castor B, Wan J, et al. 2013. Effects of calorie restriction and IGF-1 receptor blockade on the progression of 22Rv1 prostate cancer xenografts. Int J Mol Sci 14: 13782-95 [PubMed: 23823800]

59. Gillette CA, Zhu Z, Westerlind KC, Melby CL, Wolfe P, Thompson HJ. 1997. Energy availability and mammary carcinogenesis: effects of calorie restriction and exercise. Carcinogenesis 18: 11838 [PubMed: 9214601]

60. Gravaghi C, Bo J, Laperle KM, Quimby F, Kucherlapati R, et al. 2008. Obesity enhances gastrointestinal tumorigenesis in Apc-mutant mice. Int J Obes (Lond) 32: 1716-9 [PubMed: 18725892]

61. Greathouse KL, White JR, Padgett RN, Perrotta BG, Jenkins GD, et al. 2019. Gut microbiome meta-analysis reveals dysbiosis is independent of body mass index in predicting risk of obesityassociated CRC. BMJ Open Gastroenterol 6: e000247

62. Griggs JJ, Mangu PB, Anderson H, Balaban EP, Dignam JJ, et al. 2012. Appropriate chemotherapy dosing for obese adult patients with cancer: American Society of Clinical Oncology clinical practice guideline. J Clin Oncol 30: 1553-61 [PubMed: 22473167]

63. Grigura V, Barbier M, Zarov AP, Kaufman CK. 2018. Feeding amount significantly alters overt tumor onset rate in a zebrafish melanoma model. Biol Open 7

64. Gupta A, Herman Y, Ayers C, Beg MS, Lakoski SG, et al. 2016. Plasma Leptin Levels and Risk of Incident Cancer: Results from the Dallas Heart Study. PLoS One 11: e0162845 [PubMed: 27636369]

65. Gusscott S, Jenkins CE, Lam SH, Giambra V, Pollak M, Weng AP. 2016. IGF1R Derived PI3K/AKT Signaling Maintains Growth in a Subset of Human T-Cell Acute Lymphoblastic Leukemias. PLoS One 11: e0161158 [PubMed: 27532210]

66. Hanahan D, Weinberg RA. 2000. The Hallmarks of Cancer. Cell 100: 57-70 [PubMed: 10647931] 
67. Harbuzariu A, Rampoldi A, Daley-Brown DS, Candelaria P, Harmon TL, et al. 2017. Leptin-Notch signaling axis is involved in pancreatic cancer progression. Oncotarget 8: 7740-52 [PubMed: 27999190]

68. Harvey AE, Lashinger LM, Otto G, Nunez NP, Hursting SD. 2013. Decreased systemic IGF-1 in response to calorie restriction modulates murine tumor cell growth, nuclear factor-kappaB activation, and inflammation-related gene expression. Mol Carcinog 52: 997-1006 [PubMed: 22778026]

69. Hirose Y, Hata K, Kuno T, Yoshida K, Sakata K, et al. 2004. Enhancement of development of azoxymethane-induced colonic premalignant lesions in $\mathrm{C} 57 \mathrm{BL} / \mathrm{Ks} \mathrm{J}-\mathrm{db} / \mathrm{db}$ mice. Carcinogenesis 25: 821-5 [PubMed: 14729596]

70. Hosseini B, Saedisomeolia A, Allman-Farinelli M. 2017. Association Between Antioxidant Intake/ Status and Obesity: a Systematic Review of Observational Studies. Biol Trace Elem Res 175: 287-97 [PubMed: 27334437]

71. Hursting SD, Margolin BH, Switzer BR. 1993. Diet and human leukemia: an analysis of international data. Prev.Med 22: 409-22 [PubMed: 8327421]

72. Hursting SD, Perkins SN, Brown CC, Haines DC, Phang JM. 1997. Calorie restriction induces a p53-independent delay of spontaneous carcinogenesis in p53-deficient and wild-type mice. Cancer Res 57: 2843-6 [PubMed: 9230186]

73. Hursting SD, Perkins SN, Phang JM. 1994. Calorie restriction delays spontaneous tumorigenesis in p53-knockout transgenic mice. Proc Natl Acad Sci U S A 91: 7036-40 [PubMed: 8041741]

74. Incio J, Liu H, Suboj P, Chin SM, Chen IX, et al. 2016. Obesity-Induced Inflammation and Desmoplasia Promote Pancreatic Cancer Progression and Resistance to Chemotherapy. Cancer Discov 6: 852-69 [PubMed: 27246539]

75. James SJ, Muskhelishvili L. 1994. Rates of apoptosis and proliferation vary with caloric intake and may influence incidence of spontaneous hepatoma in C57BL/6 x C3H F1 mice. Cancer Res 54: 5508-10 [PubMed: 7923185]

76. Jiang W, Zhu Z, Thompson HJ. 2008. Dietary energy restriction modulates the activity of AMPactivated protein kinase, Akt, and mammalian target of rapamycin in mammary carcinomas, mammary gland, and liver. Cancer Res 68: 5492-9 [PubMed: 18593953]

77. Jiang YS, Wang FR. 2013. Caloric restriction reduces edema and prolongs survival in a mouse glioma model. J Neurooncol 114: 25-32 [PubMed: 23703297]

78. Jongbloed F, Huisman SA, van Steeg H, Pennings JLA, JNM IJ, et al. 2019. The transcriptomic response to irinotecan in colon carcinoma bearing mice preconditioned by fasting. Oncotarget 10 : 2224-34 [PubMed: 31040913]

79. Kandori H, Suzuki S, Asamoto M, Murasaki T, Mingxi T, et al. 2005. Influence of atrazine administration and reduction of calorie intake on prostate carcinogenesis in probasin/SV40 T antigen transgenic rats. Cancer Sci 96: 221-6 [PubMed: 15819720]

80. Kehm RD, Spector LG, Poynter JN, Vock DM, Altekruse SF, Osypuk TL. 2018. Does socioeconomic status account for racial and ethnic disparities in childhood cancer survival? Cancer 124: 4090-97 [PubMed: 30125340]

81. Khatua B, El-Kurdi B, Singh VP. 2017. Obesity and pancreatitis. Curr Opin Gastroenterol 33: 374-82 [PubMed: 28719397]

82. Kim JE, Lin G, Zhou J, Mund JA, Case J, Campbell WW. 2017. Weight loss achieved using an energy restriction diet with normal or higher dietary protein decreased the number of CD14(+ $+) C D 16(+)$ proinflammatory monocytes and plasma lipids and lipoproteins in middle-aged, overweight, and obese adults. Nutr Res 40: 75-84 [PubMed: 28473063]

83. Klement RJ, Champ CE, Otto C, Kammerer U. 2016. Anti-Tumor Effects of Ketogenic Diets in Mice: A Meta-Analysis. PLoS One 11: e0155050 [PubMed: 27159218]

84. Kohler LN, Garcia DO, Harris RB, Oren E, Roe DJ, Jacobs ET. 2016. Adherence to Diet and Physical Activity Cancer Prevention Guidelines and Cancer Outcomes: A Systematic Review. Cancer Epidemiol Biomarkers Prev 25: 1018-28 [PubMed: 27340121]

85. Kong Y, Dong Q, Ji H, Sang M, Ding Y, et al. 2019. The Effect of the Leptin and Leptin Receptor Expression on the Efficacy of Neoadjuvant Chemotherapy in Breast Cancer. Med Sci Monit 25: 3005-13 [PubMed: 31015393] 
86. Koru-Sengul T, Santander AM, Miao F, Sanchez LG, Jorda M, et al. 2016. Breast cancers from black women exhibit higher numbers of immunosuppressive macrophages with proliferative activity and of crown-like structures associated with lower survival compared to non-black Latinas and Caucasians. Breast Cancer Res Treat 158: 113-26 [PubMed: 27283835]

87. Kridel SJ, Axelrod F, Rozenkrantz N, Smith JW. 2004. Orlistat is a novel inhibitor of fatty acid synthase with antitumor activity. Cancer Res 64: 2070-75 [PubMed: 15026345]

88. Kusuoka O, Fujiwara-Tani R, Nakashima C, Fujii K, Ohmori H, et al. 2018. Intermittent calorie restriction enhances epithelial-mesenchymal transition through the alteration of energy metabolism in a mouse tumor model. Int J Oncol 52: 413-23 [PubMed: 29345287]

89. Lai R, Bian Z, Lin H, Ren J, Zhou H, Guo H. 2017. The association between dietary protein intake and colorectal cancer risk: a meta-analysis. World J Surg Oncol 15: 169 [PubMed: 28886717]

90. Lanza-Jacoby S, Yan G, Radice G, LePhong C, Baliff J, Hess R. 2013. Calorie restriction delays the progression of lesions to pancreatic cancer in the LSL-KrasG12D; Pdx-1/Cre mouse model of pancreatic cancer. Exp Biol Med (Maywood) 238: 787-97 [PubMed: 23828595]

91. Laron Z 2015. Lessons from 50 Years of Study of Laron Syndrome. Endocr Pract 21: 1395-402 [PubMed: 26401581]

92. Lashinger LM, Malone LM, McArthur MJ, Goldberg JA, Daniels EA, et al. 2011. Genetic reduction of insulin-like growth factor-1 mimics the anticancer effects of calorie restriction on cyclooxygenase-2-driven pancreatic neoplasia. Cancer Prev Res (Phila) 4: 1030-40 [PubMed: 21593196]

93. Leclerc GM, Leclerc GJ, Kuznetsov JN, DeSalvo J, Barredo JC. 2013. Metformin induces apoptosis through AMPK-dependent inhibition of UPR signaling in ALL lymphoblasts. PLoS One 8: e74420 [PubMed: 24009772]

94. Lee C, Raffaghello L, Brandhorst S, Safdie FM, Bianchi G, et al. 2012. Fasting cycles retard growth of tumors and sensitize a range of cancer cell types to chemotherapy. Sci Transl Med 4: $124 \mathrm{ra} 27$

95. Lee JE, Spiegelman D, Hunter DJ, Albanes D, Bernstein L, et al. 2008. Fat, protein, and meat consumption and renal cell cancer risk: a pooled analysis of 13 prospective studies. J Natl Cancer Inst 100: 1695-706 [PubMed: 19033572]

96. Levine ME, Suarez JA, Brandhorst S, Balasubramanian P, Cheng CW, et al. 2014. Low protein intake is associated with a major reduction in IGF-1, cancer, and overall mortality in the 65 and younger but not older population. Cell Metab 19: 407-17 [PubMed: 24606898]

97. Li XJ, Luo XQ, Han BW, Duan FT, Wei PP, Chen YQ. 2013. MicroRNA-100/99a, deregulated in acute lymphoblastic leukaemia, suppress proliferation and promote apoptosis by regulating the FKBP51 and IGF1R/mTOR signalling pathways. Br J Cancer 109: 2189-98 [PubMed: 24030073]

98. Lope V, Martin M, Castello A, Ruiz A, Casas AM, et al. 2019. Overeating, caloric restriction and breast cancer risk by pathologic subtype: the EPIGEICAM study. Sci Rep 9: 3904 [PubMed: 30846706]

99. Lu Z, Xie J, Wu G, Shen J, Collins R, et al. 2017. Fasting selectively blocks development of acute lymphoblastic leukemia via leptin-receptor upregulation. Nat Med 23: 79-90 [PubMed: 27941793]

100. Luo J, Chlebowski RT, Hendryx M, Rohan T, Wactawski-Wende J, et al. 2017. Intentional Weight Loss and Endometrial Cancer Risk. J Clin Oncol 35: 1189-93 [PubMed: 28165909]

101. Lussier DM, Woolf EC, Johnson JL, Brooks KS, Blattman JN, Scheck AC. 2016. Enhanced immunity in a mouse model of malignant glioma is mediated by a therapeutic ketogenic diet. BMC Cancer 16: 310 [PubMed: 27178315]

102. Lv M, Zhu X, Wang H, Wang F, Guan W. 2014. Roles of caloric restriction, ketogenic diet and intermittent fasting during initiation, progression and metastasis of cancer in animal models: a systematic review and meta-analysis. PLoS One 9: e115147 [PubMed: 25502434]

103. Ma D, Chen X, Zhang PY, Zhang H, Wei LJ, et al. 2018. Upregulation of the ALDOA/ DNA-PK/p53 pathway by dietary restriction suppresses tumor growth. Oncogene 37: 1041-48 [PubMed: 29084207]

104. Ma Z, Parris AB, Howard EW, Shi Y, Yang S, et al. 2018. Caloric restriction inhibits mammary tumorigenesis in MMTV-ErbB2 transgenic mice through the suppression of ER and 
ErbB2 pathways and inhibition of epithelial cell stemness in premalignant mammary tissues. Carcinogenesis 39: 1264-73 [PubMed: 30107476]

105. Mai V, Colbert LH, Berrigan D, Perkins SN, Pfeiffer R, et al. 2003. Calorie restriction and diet composition modulate spontaneous intestinal tumorigenesis in $\mathrm{Apc}(\mathrm{Min})$ mice through different mechanisms. Cancer Res 63: 1752-5 [PubMed: 12702556]

106. Mao Y, Tie Y, Du J. 2018. Association between dietary protein intake and prostate cancer risk: evidence from a meta-analysis. World J Surg Oncol 16: 152 [PubMed: 30041648]

107. Marsh J, Mukherjee P, Seyfried TN. 2008. Akt-dependent proapoptotic effects of dietary restriction on late-stage management of a phosphatase and tensin homologue/tuberous sclerosis complex 2-deficient mouse astrocytoma. Clin Cancer Res 14: 7751-62 [PubMed: 19047102]

108. Martin-McGill KJ, Srikandarajah N, Marson AG, Tudur Smith C, Jenkinson MD. 2018. The role of ketogenic diets in the therapeutic management of adult and paediatric gliomas: a systematic review. CNS Oncol 7: CNS17 [PubMed: 29658772]

109. Maruvada P, Leone V, Kaplan LM, Chang EB. 2017. The Human Microbiome and Obesity: Moving beyond Associations. Cell Host Microbe 22: 589-99 [PubMed: 29120742]

110. McConnell R, Gilliland FD, Goran M, Allayee H, Hricko A, Mittelman S. 2016. Does near-roadway air pollution contribute to childhood obesity? Pediatr Obes 11: 1-3 [PubMed: 25820202]

111. McCormick DL, Johnson WD, Haryu TM, Bosland MC, Lubet RA, Steele VE. 2007. Null effect of dietary restriction on prostate carcinogenesis in the Wistar-Unilever rat. Nutr Cancer 57: 194200 [PubMed: 17571953]

112. McQuade JL, Daniel CR, Hess KR, Mak C, Wang DY, et al. 2018. Association of bodymass index and outcomes in patients with metastatic melanoma treated with targeted therapy, immunotherapy, or chemotherapy: a retrospective, multicohort analysis. Lancet Oncol 19: 31022 [PubMed: 29449192]

113. Miller KD, Goding Sauer A, Ortiz AP, Fedewa SA, Pinheiro PS, et al. 2018. Cancer Statistics for Hispanics/Latinos, 2018. CA Cancer J Clin 68: 425-45 [PubMed: 30285281]

114. Mizuno NK, Rogozina OP, Seppanen CM, Liao DJ, Cleary MP, Grossmann ME. 2013. Combination of intermittent calorie restriction and eicosapentaenoic acid for inhibition of mammary tumors. Cancer Prev Res (Phila) 6: 540-7 [PubMed: 23550153]

115. Molina-Aguilar C, Guerrero-Carrillo MJ, Espinosa-Aguirre JJ, Olguin-Reyes S, Castro-Belio T, et al. 2017. Time-caloric restriction inhibits the neoplastic transformation of cirrhotic liver in rats treated with diethylnitrosamine. Carcinogenesis 38: 847-58 [PubMed: 28535183]

116. Moore T, Beltran L, Carbajal S, Hursting SD, DiGiovanni J. 2012. Energy balance modulates mouse skin tumor promotion through altered IGF-1R and EGFR crosstalk. Cancer Prev Res (Phila) 5: 1236-46 [PubMed: 22896210]

117. Morris PG, Hudis CA, Giri D, Morrow M, Falcone DJ, et al. 2011. Inflammation and Increased Aromatase Expression Occur in the Breast Tissue of Obese Women with Breast Cancer. Cancer Prevention Research 4: 1021-29 [PubMed: 21622727]

118. Morscher RJ, Aminzadeh-Gohari S, Feichtinger RG, Mayr JA, Lang R, et al. 2015. Inhibition of Neuroblastoma Tumor Growth by Ketogenic Diet and/or Calorie Restriction in a CD1-Nu Mouse Model. PLoS One 10: e0129802 [PubMed: 26053068]

119. Morscher RJ, Aminzadeh-Gohari S, Hauser-Kronberger C, Feichtinger RG, Sperl W, Kofler B. 2016. Combination of metronomic cyclophosphamide and dietary intervention inhibits neuroblastoma growth in a CD1-nu mouse model. Oncotarget 7: 17060-73 [PubMed: 26959744]

120. Newman LA, Kaljee LM. 2017. Health Disparities and Triple-Negative Breast Cancer in African American Women: A Review. JAMA Surg 152: 485-93 [PubMed: 28355428]

121. Nieman KM, Kenny HA, Penicka CV, Ladanyi A, Buell-Gutbrod R, et al. 2011. Adipocytes promote ovarian cancer metastasis and provide energy for rapid tumor growth. Nat.Med 17: 1498-503 [PubMed: 22037646]

122. Nieman KM, Romero IL, Van Houten B, Lengyel E. 2013. Adipose tissue and adipocytes support tumorigenesis and metastasis. Biochim Biophys Acta 1831: 1533-41 [PubMed: 23500888] 
123. Nogueira LM, Dunlap SM, Ford NA, Hursting SD. 2012. Calorie restriction and rapamycin inhibit MMTV-Wnt-1 mammary tumor growth in a mouse model of postmenopausal obesity. Endocr Relat Cancer 19: 57-68 [PubMed: 22143497]

124. Nottage KA, Ness KK, Li C, Srivastava D, Robison LL, Hudson MM. 2014. Metabolic syndrome and cardiovascular risk among long-term survivors of acute lymphoblastic leukaemia - From the St. Jude Lifetime Cohort. Br J Haematol 165: 364-74 [PubMed: 24467690]

125. O'Keefe SJ. 2016. Diet, microorganisms and their metabolites, and colon cancer. Nat Rev Gastroenterol Hepatol 13: 691-706 [PubMed: 27848961]

126. Oppezzo P, Vasconcelos Y, Settegrana C, Jeannel D, Vuillier F, et al. 2005. The LPL/ADAM29 expression ratio is a novel prognosis indicator in chronic lymphocytic leukemia. Blood 106: 650-57 [PubMed: 15802535]

127. Orgel E, Genkinger JM, Aggarwal D, Sung L, Nieder M, Ladas EJ. 2016. Association of body mass index and survival in pediatric leukemia: a meta-analysis. Am J Clin Nutr 103: 808-17 [PubMed: 26864366]

128. Orgel E, Mueske NM, Sposto R, Gilsanz V, Freyer DR, Mittelman SD. 2016. Limitations of body mass index to assess body composition due to sarcopenic obesity during leukemia therapy. Leuk Lymphoma: 1-8

129. Pang Y, Wang W. 2018. Dietary protein intake and risk of ovarian cancer: evidence from a meta-analysis of observational studies. Biosci Rep 38

130. Pape-Ansorge KA, Grande JP, Christensen TA, Maihle NJ, Cleary MP. 2002. Effect of moderate caloric restriction and/or weight cycling on mammary tumor incidence and latency in MMTVNeu female mice. Nutr Cancer 44: 162-8 [PubMed: 12734063]

131. Parekh N, Chandran U, Bandera EV. 2012. Obesity in cancer survival. Annu Rev Nutr 32: 311-42 [PubMed: 22540252]

132. Pavlides S, Whitaker-Menezes D, Castello-Cros R, Flomenberg N, Witkiewicz AK, et al. 2009. The reverse Warburg effect: Aerobic glycolysis in cancer associated fibroblasts and the tumor stroma. Cell Cycle 8: 3984-4001 [PubMed: 19923890]

133. Phoenix KN, Vumbaca F, Fox MM, Evans R, Claffey KP. 2010. Dietary energy availability affects primary and metastatic breast cancer and metformin efficacy. Breast Cancer Res Treat 123: 33344 [PubMed: 20204498]

134. Pinkston JM, Garigan D, Hansen M, Kenyon C. 2006. Mutations that increase the life span of C. elegans inhibit tumor growth. Science 313: 971-5 [PubMed: 16917064]

135. Ploeger JM, Manivel JC, Boatner LN, Mashek DG. 2017. Caloric Restriction Prevents Carcinogen-Initiated Liver Tumorigenesis in Mice. Cancer Prev Res (Phila) 10: 660-70 [PubMed: 28847977]

136. Psaltopoulou T, Kosti RI, Haidopoulos D, Dimopoulos M, Panagiotakos DB. 2011. Olive oil intake is inversely related to cancer prevalence: a systematic review and a meta-analysis of 13,800 patients and 23,340 controls in 19 observational studies. Lipids Health Dis 10: 127 [PubMed: 21801436]

137. Raffaghello L, Lee C, Safdie FM, Wei M, Madia F, et al. 2008. Starvation-dependent differential stress resistance protects normal but not cancer cells against high-dose chemotherapy. Proc Natl Acad Sci U S A 105: 8215-20 [PubMed: 18378900]

138. Ramsey MM, Ingram RL, Cashion AB, Ng AH, Cline JM, et al. 2002. Growth hormonedeficient dwarf animals are resistant to dimethylbenzanthracine (DMBA)-induced mammary carcinogenesis. Endocrinology 143: 4139-42 [PubMed: 12239127]

139. Rapp K, Schroeder J, Klenk J, Stoehr S, Ulmer H, et al. 2005. Obesity and incidence of cancer: a large cohort study of over 145,000 adults in Austria. Br J Cancer 93: 1062-7 [PubMed: 16234822]

140. Renehan AG, Tyson M, Egger M, Heller RF, Zwahlen M. 2008. Body-mass index and incidence of cancer: a systematic review and meta-analysis of prospective observational studies. Lancet 371: 569-78 [PubMed: 18280327]

141. Richman EL, Kenfield SA, Chavarro JE, Stampfer MJ, Giovannucci EL, et al. 2013. Fat intake after diagnosis and risk of lethal prostate cancer and all-cause mortality. JAMA Intern Med 173: 1318-26 [PubMed: 23752662] 
142. Richter JE, Rubenstein JH. 2018. Presentation and Epidemiology of Gastroesophageal Reflux Disease. Gastroenterology 154: 267-76 [PubMed: 28780072]

143. Rocha NS, Barbisan LF, de Oliveira ML, de Camargo JL. 2002. Effects of fasting and intermittent fasting on rat hepatocarcinogenesis induced by diethylnitrosamine. Teratog Carcinog Mutagen 22: 129-38 [PubMed: 11835290]

144. Rossi EL, Dunlap SM, Bowers LW, Khatib SA, Doerstling SS, et al. 2017. Energy Balance Modulation Impacts Epigenetic Reprogramming, ERalpha and ERbeta Expression, and Mammary Tumor Development in MMTV-neu Transgenic Mice. Cancer Res 77: 2500-11 [PubMed: 28373182]

145. Rouhani MH, Salehi-Abargouei A, Surkan PJ, Azadbakht L. 2014. Is there a relationship between red or processed meat intake and obesity? A systematic review and meta-analysis of observational studies. Obes Rev 15: 740-8 [PubMed: 24815945]

146. Roy S, Trinchieri G. 2017. Microbiota: a key orchestrator of cancer therapy. Nat Rev Cancer 17: 271-85 [PubMed: 28303904]

147. Safdie FM, Dorff T, Quinn D, Fontana L, Wei M, et al. 2009. Fasting and cancer treatment in humans: A case series report. Aging (Albany NY) 1: 988-1007 [PubMed: 20157582]

148. Saleh AD, Simone BA, Palazzo J, Savage JE, Sano Y, et al. 2013. Caloric restriction augments radiation efficacy in breast cancer. Cell Cycle 12: 1955-63 [PubMed: 23708519]

149. Samudio I, Harmancey R, Fiegl M, Kantarjian H, Konopleva M, et al. 2010. Pharmacologic inhibition of fatty acid oxidation sensitizes human leukemia cells to apoptosis induction. $\mathrm{J}$ Clin.Invest 120: 142-56 [PubMed: 20038799]

150. Sayon-Orea C, Martinez-Gonzalez MA, Bes-Rastrollo M. 2011. Alcohol consumption and body weight: a systematic review. Nutr Rev 69: 419-31 [PubMed: 21790610]

151. Schwingshackl L, Hoffmann G. 2015. Adherence to Mediterranean diet and risk of cancer: an updated systematic review and meta-analysis of observational studies. Cancer Med 4: 1933-47 [PubMed: 26471010]

152. Seibert RG, Hanchate AD, Berz JP, Schroy PC 3rd. 2017. National Disparities in Colorectal Cancer Screening Among Obese Adults. Am J Prev Med 53: e41-e49 [PubMed: 28236517]

153. Seyfried TN, Sanderson TM, El-Abbadi MM, McGowan R, Mukherjee P. 2003. Role of glucose and ketone bodies in the metabolic control of experimental brain cancer. Br J Cancer 89: 137582 [PubMed: 14520474]

154. Shelton LM, Huysentruyt LC, Mukherjee P, Seyfried TN. 2010. Calorie restriction as an antiinvasive therapy for malignant brain cancer in the VM mouse. ASN Neuro 2: e00038 [PubMed: 20664705]

155. Sheng X, Parmentier JH, Tucci J, Pei H, Cortez-Toledo O, et al. 2017. Adipocytes Sequester and Metabolize the Chemotherapeutic Daunorubicin. Mol Cancer Res 15: 1704-13 [PubMed: 29117945]

156. Shields BA, Engelman RW, Fukaura Y, Good RA, Day NK. 1991. Calorie restriction suppresses subgenomic mink cytopathic focus-forming murine leukemia virus transcription and frequency of genomic expression while impairing lymphoma formation. Proc Natl Acad Sci U S A 88: 11138-42 [PubMed: 1763029]

157. Shu XO, Zheng Y, Cai H, Gu K, Chen Z, et al. 2009. Soy food intake and breast cancer survival. JAMA 302: 2437-43 [PubMed: 19996398]

158. Siegel RL, Miller KD, Jemal A. 2017. Cancer Statistics, 2017. CA Cancer J Clin 67: 7-30 [PubMed: 28055103]

159. Sikalidis AK, Fitch MD, Fleming SE. 2013. Diet induced obesity increases the risk of colonic tumorigenesis in mice. Pathol Oncol Res 19: 657-66 [PubMed: 23536280]

160. Simone BA, Dan T, Palagani A, Jin L, Han SY, et al. 2016. Caloric restriction coupled with radiation decreases metastatic burden in triple negative breast cancer. Cell Cycle 15: 2265-74 [PubMed: 27027731]

161. Simone BA, Palagani A, Strickland K, Ko K, Jin L, et al. 2018. Caloric restriction counteracts chemotherapy-induced inflammation and increases response to therapy in a triple negative breast cancer model. Cell Cycle 17: 1536-44 [PubMed: 29912618] 
162. Sinicrope FA, Foster NR, Sargent DJ, O'Connell MJ, Rankin C. 2010. Obesity is an independent prognostic variable in colon cancer survivors. Clin Cancer Res 16: 1884-93 [PubMed: 20215553]

163. Slavin JL. 2005. Dietary fiber and body weight. Nutrition 21: 411-8 [PubMed: 15797686]

164. Song M, Fung TT, Hu FB, Willett WC, Longo VD, et al. 2016. Association of Animal and Plant Protein Intake With All-Cause and Cause-Specific Mortality. JAMA Intern Med 176: 1453-63 [PubMed: 27479196]

165. Stewart JW, Koehler K, Jackson W, Hawley J, Wang W, et al. 2005. Prevention of mouse skin tumor promotion by dietary energy restriction requires an intact adrenal gland and glucocorticoid supplementation restores inhibition. Carcinogenesis 26: 1077-84 [PubMed: 15746164]

166. Sun P, Wang H, He Z, Chen X, Wu Q, et al. 2017. Fasting inhibits colorectal cancer growth by reducing M2 polarization of tumor-associated macrophages. Oncotarget 8: 74649-60 [PubMed: 29088814]

167. Suttie AW, Dinse GE, Nyska A, Moser GJ, Goldsworthy TL, Maronpot RR. 2005. An investigation of the effects of late-onset dietary restriction on prostate cancer development in the TRAMP mouse. Toxicol Pathol 33: 386-97 [PubMed: 15805078]

168. Tabe Y, Yamamoto S, Saitoh K, Sekihara K, Monma N, et al. 2017. Bone Marrow Adipocytes Facilitate Fatty Acid Oxidation Activating AMPK and a Transcriptional Network Supporting Survival of Acute Monocytic Leukemia Cells. Cancer Res 77: 1453-64 [PubMed: 28108519]

169. Tagliaferro AR, Ronan AM, Meeker LD, Thompson HJ, Scott AL, Sinha D. 1996. Cyclic food restriction alters substrate utilization and abolishes protection from mammary carcinogenesis female rats. J Nutr 126: 1398-405 [PubMed: 8618136]

170. Thomas JA 2nd, Antonelli JA, Lloyd JC, Masko EM, Poulton SH, et al. 2010. Effect of intermittent fasting on prostate cancer tumor growth in a mouse model. Prostate Cancer Prostatic Dis 13: 350-5 [PubMed: 20733612]

171. Thompson HJ, McGinley JN, Spoelstra NS, Jiang W, Zhu Z, Wolfe P. 2004. Effect of dietary energy restriction on vascular density during mammary carcinogenesis. Cancer Res 64: 5643-50 [PubMed: 15313902]

172. Tomasi C, Laconi E, Laconi S, Greco M, Sarma DS, Pani P. 1999. Effect of fasting/refeeding on the incidence of chemically induced hepatocellular carcinoma in the rat. Carcinogenesis 20: 1979-83 [PubMed: 10506114]

173. Tomita M 2012. Caloric restriction reduced 1, 2-dimethylhydrazine-induced aberrant crypt foci and induces the expression of Sirtuins in colonic mucosa of F344 rats. J Carcinog 11: 10 [PubMed: 22919283]

174. Tsao JL, Dudley S, Kwok B, Nickel AE, Laird PW, et al. 2002. Diet, cancer and aging in DNA mismatch repair deficient mice. Carcinogenesis 23: 1807-10 [PubMed: 12419828]

175. Tsilidis KK, Kasimis JC, Lopez DS, Ntzani EE, Ioannidis JP. 2015. Type 2 diabetes and cancer: umbrella review of meta-analyses of observational studies. BMJ 350: g7607 [PubMed: 25555821]

176. Tucci J, Alhushki W, Chen T, Sheng X, Kim YM, Mittelman SD. 2018. Switch to low-fat diet improves outcome of acute lymphoblastic leukemia in obese mice. Cancer Metab 6: 15 [PubMed: 30410754]

177. van Ginhoven TM, van den Berg JW, Dik WA, Ijzermans JN, de Bruin RW. 2010. Preoperative dietary restriction reduces hepatic tumor load by reduced E-selectin-mediated adhesion in mice. J Surg Oncol 102: 348-53 [PubMed: 20672315]

178. Von Tungeln LS, Bucci TJ, Hart RW, Kadlubar FF, Fu PP. 1996. Inhibitory effect of caloric restriction on tumorigenicity induced by 4-aminobiphenyl and 2-amino-1-methyl-6phenylimidazo-[4,5-b]pyridine (PhIP) in the CD1 newborn mouse bioassay. Cancer Lett 104: 133-6 [PubMed: 8665480]

179. Wang T, Fahrmann JF, Lee H, Li YJ, Tripathi SC, et al. 2018. JAK/STAT3-Regulated Fatty Acid beta-Oxidation Is Critical for Breast Cancer Stem Cell Self-Renewal and Chemoresistance. Cell Metab 27: 136-50 e5 [PubMed: 29249690]

180. Warburg O 1925. The Metabolism of Carcinoma Cells. The Journal of Cancer Research 9: 14863 
181. Ward E, Jemal A, Cokkinides V, Singh GK, Cardinez C, et al. 2004. Cancer disparities by race/ ethnicity and socioeconomic status. CA Cancer J Clin 54: 78-93 [PubMed: 15061598]

182. Woolf EC, Curley KL, Liu Q, Turner GH, Charlton JA, et al. 2015. The Ketogenic Diet Alters the Hypoxic Response and Affects Expression of Proteins Associated with Angiogenesis, Invasive Potential and Vascular Permeability in a Mouse Glioma Model. PLoS One 10: e0130357 [PubMed: 26083629]

183. Wu J, Zeng R, Huang J, Li X, Zhang J, et al. 2016. Dietary Protein Sources and Incidence of Breast Cancer: A Dose-Response Meta-Analysis of Prospective Studies. Nutrients 8

184. Xu XD, Shao SX, Jiang HP, Cao YW, Wang YH, et al. 2015. Warburg Effect or Reverse Warburg Effect? A Review of Cancer Metabolism. Oncology Research and Treatment 38: 117 22 [PubMed: 25792083]

185. Yakar S, Nunez NP, Pennisi P, Brodt P, Sun H, et al. 2006. Increased tumor growth in mice with diet-induced obesity: impact of ovarian hormones. Endocrinology 147: 5826-34 [PubMed: 16959846]

186. Yamaza H, Komatsu T, Wakita S, Kijogi C, Park S, et al. 2010. FoxO1 is involved in the antineoplastic effect of calorie restriction. Aging Cell 9: 372-82 [PubMed: 20222901]

187. Yang HS, Yoon C, Myung SK, Park SM. 2011. Effect of obesity on survival of women with epithelial ovarian cancer: a systematic review and meta-analysis of observational studies. Int $\mathbf{J}$ Gynecol Cancer 21: 1525-32 [PubMed: 22080892]

188. Yeung CY, Tso AW, Xu A, Wang Y, Woo YC, et al. 2013. Pro-inflammatory adipokines as predictors of incident cancers in a Chinese cohort of low obesity prevalence in Hong Kong. PLoS One 8: e78594 [PubMed: 24205276]

189. Yoshimoto S, Loo TM, Atarashi K, Kanda H, Sato S, et al. 2013. Obesity-induced gut microbial metabolite promotes liver cancer through senescence secretome. Nature 499: 97-101 [PubMed: 23803760]

190. Yuan C, Bao Y, Wu C, Kraft P, Ogino S, et al. 2013. Prediagnostic body mass index and pancreatic cancer survival. J Clin Oncol 31: 4229-34 [PubMed: 24145341]

191. Yuhara H, Steinmaus C, Cohen SE, Corley DA, Tei Y, Buffler PA. 2011. Is diabetes mellitus an independent risk factor for colon cancer and rectal cancer? Am J Gastroenterol 106: 1911-21; quiz 22 [PubMed: 21912438]

192. Yun JP, Behan JW, Heisterkamp N, Butturini A, Klemm L, et al. 2010. Diet-Induced Obesity Accelerates Acute Lymphoblastic Leukemia Progression in Two Murine Models. Cancer Prev.Res (Phila Pa) 3: 1259-64

193. Zaytouni T, Tsai PY, Hitchcock DS, DuBois CD, Freinkman E, et al. 2017. Critical role for arginase 2 in obesity-associated pancreatic cancer. Nat Commun 8: 242 [PubMed: 28808255]

194. Zhang J, Jia PP, Liu QL, Cong MH, Gao Y, et al. 2018. Low ketolytic enzyme levels in tumors predict ketogenic diet responses in cancer cell lines in vitro and in vivo. J Lipid Res 59: 625-34 [PubMed: 29414764]

195. Zhang J, Pavlova NN, Thompson CB. 2017. Cancer cell metabolism: the essential role of the nonessential amino acid, glutamine. EMBO J 36: 1302-15 [PubMed: 28420743]

196. Zhu Y, Aupperlee MD, Haslam SZ, Schwartz RC. 2017. Pubertally Initiated High-Fat Diet Promotes Mammary Tumorigenesis in Obesity-Prone FVB Mice Similarly to Obesity-Resistant BALB/c Mice. Transl Oncol 10: 928-35 [PubMed: 29024822]

197. Zhuang Y, Chan DK, Haugrud AB, Miskimins WK. 2014. Mechanisms by which low glucose enhances the cytotoxicity of metformin to cancer cells both in vitro and in vivo. PLoS One 9: e108444 [PubMed: 25254953]

198. Zoico E, Rizzatti V, Darra E, Budui SL, Franceschetti G, et al. 2017. Morphological and Functional Changes in the Peritumoral Adipose Tissue of Colorectal Cancer Patients. Obesity (Silver Spring) 25 Suppl 2: S87-S94 [PubMed: 29086519] 
Table 1:

Preclinical studies examining the role of fasting on cancer outcome

\begin{tabular}{|c|c|c|c|c|c|c|}
\hline Cancer (cell line) & Animal & Route & Fasting Scheme & $\begin{array}{l}\text { Effect of } \\
\text { fasting alone }\end{array}$ & $\begin{array}{l}\text { Effect of fasting with } \\
\text { treatment }\end{array}$ & Ref \\
\hline \multicolumn{7}{|l|}{ Immunocompetent } \\
\hline $\begin{array}{l}\text { Breast (67NR and } \\
4 \mathrm{~T} 1)\end{array}$ & 14 week old BALB/c & Orthotopic & $\mathrm{ADF}$ & $\begin{array}{l}\text { Slowed tumor } \\
\text { growth }\end{array}$ & Synergy with irradiation & (148) \\
\hline Breast (4T1) & $\begin{array}{l}12 \text { week old BALB/c } \\
\text { female }\end{array}$ & SQ & $\begin{array}{l}\text { Two } 48-60 \text { hour } \\
\text { fasting cycles }\end{array}$ & $\begin{array}{l}\text { Slowed tumor } \\
\text { growth }\end{array}$ & $\begin{array}{l}\text { Synergy with } \\
\text { cyclophosphamide }\end{array}$ & (94) \\
\hline Breast (4T1) & $\begin{array}{l}12 \text { week old BALB/c } \\
\text { female }\end{array}$ & IV & One 48 hour fast & n.a. & $\begin{array}{l}\text { Synergy with } \\
\text { cyclophosphamide to prolong } \\
\text { survival }\end{array}$ & (94) \\
\hline Colorectal (CT26) & $\begin{array}{l}6 \text { week old female } \\
\text { BALB/c }\end{array}$ & SQ & $\begin{array}{l}\text { Two } 48 \text { hour } \\
\text { fasting cycles }\end{array}$ & $\begin{array}{l}\text { Slowed tumor } \\
\text { growth }\end{array}$ & Synergy with oxaliplatin & (17) \\
\hline Melanoma (B16) & $\begin{array}{l}12 \text { week old } \\
\text { C57BL/6 male \& } \\
\text { female }\end{array}$ & SQ & $\begin{array}{l}48-60 \text { hour } \\
\text { fasting cycles }\end{array}$ & $\begin{array}{l}\text { Slowed tumor } \\
\text { growth }\end{array}$ & Synergy with doxorubicin & (94) \\
\hline Melanoma (B16) & $\begin{array}{l}12 \text { week old } \\
\text { C57BL/6 male \& } \\
\text { female }\end{array}$ & IV & One 48 hour fast & $\begin{array}{l}\text { No sustained } \\
\text { benefit }\end{array}$ & $\begin{array}{l}\text { Synergy with doxorubicin to } \\
\text { prolong survival }\end{array}$ & (94) \\
\hline $\begin{array}{l}\text { Neuroblastoma } \\
\text { (NXS2) }\end{array}$ & $\begin{array}{l}\text { 6-7 week old female } \\
\text { A/J }\end{array}$ & IV & One 48 hour fast & No benefit & $\begin{array}{l}\text { Less treatment toxicity of one } \\
\text { high dose of etoposide, but } \\
\text { more rapid tumor progression }\end{array}$ & (137) \\
\hline $\begin{array}{l}\text { Neuroblastoma } \\
\text { (NXS2) }\end{array}$ & $\begin{array}{l}6 \text { week old female } \\
\text { A/J }\end{array}$ & IV & $\begin{array}{l}\text { Two } 48 \text { hour } \\
\text { fasting cycles }\end{array}$ & n.a. & $\begin{array}{l}\text { Synergy with doxorubicin to } \\
\text { prolong survival }\end{array}$ & (94) \\
\hline $\begin{array}{l}\text { Neuroblastoma } \\
\text { (Neuro 2A) }\end{array}$ & $\begin{array}{l}6 \text { week old female } \\
\text { A/J }\end{array}$ & IV & One 48 hour fast & n.a. & $\begin{array}{l}\text { Synergy with doxorubicin and } \\
\text { cisplatin cocktail to prolong } \\
\text { survival }\end{array}$ & (94) \\
\hline Pancreatic (KPC) & $\begin{array}{l}9 \text { week old male and } \\
\text { female C57BL/6J }\end{array}$ & Orthotopic & 24 hour fast & No benefit & Synergy with irradiation & (39) \\
\hline \multicolumn{7}{|l|}{ Immunocompromised } \\
\hline $\begin{array}{l}\text { Breast (MDA- } \\
\text { MB-231) }\end{array}$ & $\begin{array}{l}\text { 5-7 week old nude } \\
\text { mice }\end{array}$ & SQ & $\begin{array}{l}\text { Four } 48 \text { hour } \\
\text { fasting cycles }\end{array}$ & $\begin{array}{l}\text { No sustained } \\
\text { benefit }\end{array}$ & $\begin{array}{l}\text { No apparent synergy with } \\
\text { doxorubicin }\end{array}$ & (94) \\
\hline Breast (H3122) & $\begin{array}{l}\text { 6-8 week old } \\
\text { athymic BALB/c } \\
\text { mice }\end{array}$ & SQ & $\begin{array}{l}\text { Three } 48 \text { hour } \\
\text { fasting cycles }\end{array}$ & $\begin{array}{l}\text { Slowed tumor } \\
\text { growth }\end{array}$ & $\begin{array}{l}\text { Synergy with crizotinib } \\
\text { (tyrosine kinase inhibitor) }\end{array}$ & (26) \\
\hline $\begin{array}{l}\text { Colorectal } \\
\text { (HCT116) }\end{array}$ & $\begin{array}{l}\text { 6-8 week old } \\
\text { athymic BALB/c } \\
\text { mice }\end{array}$ & SQ & $\begin{array}{l}\text { Three } 48 \text { hour } \\
\text { fasting cycles }\end{array}$ & $\begin{array}{l}\text { Slowed tumor } \\
\text { growth }\end{array}$ & $\begin{array}{l}\text { Synergy with regorafenib } \\
\text { (tyrosine kinase inhibitor) }\end{array}$ & (26) \\
\hline Glioma (GL26) & $\begin{array}{l}7 \text { week old nude } \\
\text { mice }\end{array}$ & SQ & $\begin{array}{l}48-60 \text { hour } \\
\text { fasting cycles }\end{array}$ & $\begin{array}{l}\text { Slowed tumor } \\
\text { growth }\end{array}$ & Synergy with doxorubicin & (94) \\
\hline Ovarian (OVCAR3) & $\begin{array}{l}\text { 5-7 week old nude } \\
\text { mice }\end{array}$ & SQ & $\begin{array}{l}\text { Two } 48 \text { hour } \\
\text { fasting cycles }\end{array}$ & $\begin{array}{l}\text { No sustained } \\
\text { benefit }\end{array}$ & $\begin{array}{l}\text { No apparent synergy with } \\
\text { doxorubicin }\end{array}$ & (94) \\
\hline
\end{tabular}

n.a. $=$ not assessed $; \mathrm{ADF}=$ alternate day feeding; $\mathrm{IV}=$ intravenous; $\mathrm{SQ}=$ subcutaneous 
Table 2:

Preclinical studies examining the role of caloric restriction on cancer outcome

\begin{tabular}{|c|c|c|c|c|c|c|}
\hline $\begin{array}{l}\text { Cancer (cell } \\
\text { line) }\end{array}$ & Animal & Route & Diet Scheme & $\begin{array}{l}\text { Effect of diet } \\
\text { alone }\end{array}$ & Effect of diet with treatment & Ref \\
\hline B-ALL (8093) & C57BL/6J & Retroorbital & $\begin{array}{l}\text { Switch from } 60 \% \\
\text { to } 10 \% \text { fat diet }\end{array}$ & No benefit & $\begin{array}{l}\text { Improved efficacy of vincristine, } \\
\text { but no effect on dexamethasone or } \\
\text { L-asparaginase }\end{array}$ & (176) \\
\hline Breast (4T1) & $\begin{array}{l}8-14 \text { week old } \\
\text { BALB/c }\end{array}$ & Orthotopic & $70 \%$ of $\mathrm{AL}$ & $\begin{array}{l}\text { Slowed tumor } \\
\text { growth }\end{array}$ & $\begin{array}{l}\text { Synergy with irradiation, } \\
\text { cisplatin, and docetaxol }\end{array}$ & $\begin{array}{l}(148, \\
160,161)\end{array}$ \\
\hline Breast (4T1) & $\begin{array}{l}12-15 \text { wk old } \\
\text { BALB/c mice }\end{array}$ & SQ & $50 \%$ of $\mathrm{AL}$ & n.a. & No synergy with cisplatin & (22) \\
\hline
\end{tabular}

$\mathrm{SQ}=$ subcutaneous 
Table 3:

Preclinical trials of ketogenic diets on cancer outcome

\begin{tabular}{|c|c|c|c|c|c|c|}
\hline Cancer (cell line) & Animal & Route & Diet Scheme & $\begin{array}{l}\text { Effect of diet } \\
\text { alone }\end{array}$ & $\begin{array}{l}\text { Effect of diet with } \\
\text { treatment }\end{array}$ & Ref \\
\hline Breast (4T1) & $\begin{array}{l}\mathrm{BALB} / \mathrm{C} \\
\text { mice }\end{array}$ & SQ & $\begin{array}{l}70 \% \text { of } \mathrm{AL} \text { of } 2 \% \\
\mathrm{CHO} \text { and } 93.4 \% \\
\text { fat calories diet }\end{array}$ & $\begin{array}{l}\text { Reduced tumor } \\
\text { growth }\end{array}$ & $\begin{array}{l}\text { Enhanced antitumor effect } \\
\text { of metformin }\end{array}$ & (197) \\
\hline Glioma (GL261 cells) & $\begin{array}{l}\text { Male albino } \\
\text { C57BL/6 } \\
\text { mice }\end{array}$ & Orthotopic & $\begin{array}{l}\text { AL } 3 \% \text { CHO and } \\
72 \% \text { fat calories } \\
\text { diet }\end{array}$ & Prolonged survival & Synergy with irradiation & $\begin{array}{l}(3, \\
101)\end{array}$ \\
\hline Glioma (GL261) & $\begin{array}{l}\text { Female } \\
\text { albino } \\
\text { C57BL/6 }\end{array}$ & Orthotopic & $\begin{array}{l}\text { AL } 3 \% \text { CHO and } \\
72 \% \text { fat calories } \\
\text { diet }\end{array}$ & Prolonged survival & $\begin{array}{l}\text { Synergistic with whole } \\
\text { brain irradiation }\end{array}$ & $\begin{array}{l}(3, \\
182)\end{array}$ \\
\hline $\begin{array}{l}\text { Lung (NCI-H292 and } \\
\text { A549 cells) }\end{array}$ & $\begin{array}{l}\text { Female } \\
\text { athymic- } \\
\text { nu/nu mice }\end{array}$ & SQ & $\begin{array}{l}\text { AL } 1.6 \% \text { CHO } \\
\text { and } 90 \% \text { fat } \\
\text { calories diet }\end{array}$ & $\begin{array}{l}\text { No effect of KD } \\
\text { alone on tumor } \\
\text { volume or survival }\end{array}$ & $\begin{array}{l}\text { Enhanced tumor response } \\
\text { and survival with irradiation } \\
\pm \text { carboplatin }\end{array}$ & (5) \\
\hline $\begin{array}{l}\text { Medulloblastoma } \\
\text { (cells from above } \\
\text { mice) }\end{array}$ & NOD/SCID & SQ & $\begin{array}{l}\text { AL 6:1 3.2\% CHO } \\
\text { and } 75.1 \% \text { fat } \\
\text { paste diet }\end{array}$ & $\begin{array}{l}\text { No effect on tumor } \\
\text { growth }\end{array}$ & $\begin{array}{l}\text { No effect on SMO inhibitor } \\
\text { GDC- } 0449 \text { antitumor } \\
\text { activity }\end{array}$ & $(37)$ \\
\hline $\begin{array}{l}\text { Neuroblastoma (SK- } \\
\text { N-BE( } 2) \text { and SH- } \\
\text { SY5Y cells) }\end{array}$ & $\begin{array}{l}\text { Female } \\
\text { CD1-nu }\end{array}$ & SQ & $\begin{array}{l}\mathrm{AL} \text { or } 2 / 3 \mathrm{AL} \mathrm{KD} \\
\text { with } 8 \% \mathrm{CHO} \text { and } \\
78 \% \text { fat calories }\end{array}$ & $\begin{array}{l}\text { CR KD slowed } \\
\text { tumor growth and } \\
\text { prolonged survival } \\
\text { of both tumors. AL } \\
\text { KD only slowed } \\
\text { tumor growth and } \\
\text { prolonged survival } \\
\text { for SK-N-BE(2) } \\
\text { tumors }\end{array}$ & $\begin{array}{l}\text { Both diets slowed growth } \\
\text { of KH-SY5Y tumors but } \\
\text { not SK-N-BE(2) tumors } \\
\text { during cyclophosphamide } \\
\text { treatment }\end{array}$ & $\begin{array}{l}(118, \\
119)\end{array}$ \\
\hline
\end{tabular}

AL: ad libitum; CHO: carbohydrates; KD: ketogenic diet; SMO: smoothened gene, a component of the sonic hedgehog pathway. 